PROCÁSSIA MARIA DE OLIVEIRA LACERDA

Aspectos estereológicos dos vilos coriônicos da placenta de bovinos clonados

SÃO PAULO

2006 


\section{Aspectos estereológicos dos vilos coriônicos da placenta de bovinos clonados}

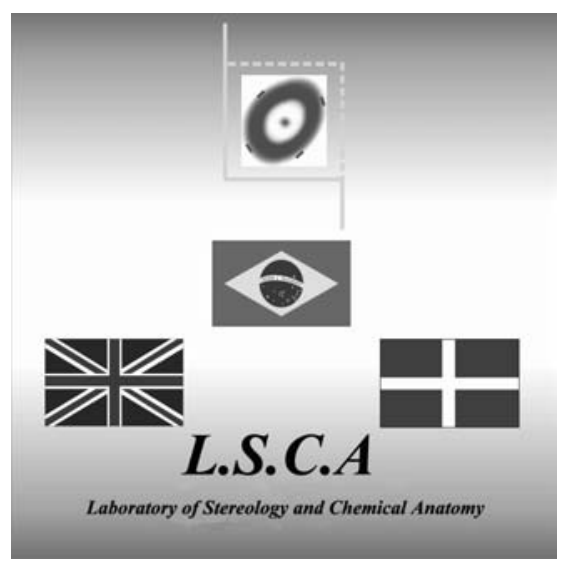

Dissertação apresentada ao Programa de Pósgraduação em Anatomia dos Animais Domésticos e Silvestres da Faculdade de Medicina Veterinária e Zootecnia da Universidade de São Paulo para obtenção do título de Mestre em Ciências.

\section{Departamento:}

Cirurgia

Área de Concentração:

Anatomia dos Animais Domésticos e Silvestres

\section{Orientador:}

Prof. Dr. Antonio Augusto Coppi Maciel Ribeiro 
Autorizo a reprodução parcial ou total desta obra, para fins acadêmicos, desde que citada a fonte.

DADOS INTERNACIONAIS DE CATALOGAÇÃO-NA-PUBLICAÇÃO

(Biblioteca Virginie Buff D’Ápice da Faculdade de Medicina Veterinária e Zootecnia da Universidade de São Paulo)

T.1669 Lacerda, Procássia Maria de Oliveira

FMVZ Aspectos estereológicos dos vilos coriônicos da placenta de bovinos clonados / Procássia Maria de Oliveira Lacerda. - São Paulo: P. M. O. Lacerda, 2006.

$77 \mathrm{f}$. : il.

Dissertação (mestrado) - Universidade de São Paulo. Faculdade de Medicina Veterinária e Zootecnia. Departamento de Cirurgia, 2006.

Programa de Pós-graduação: Anatomia dos Animais Domésticos e Silvestres.

Área de concentração: Anatomia dos Animais Domésticos e Silvestres.

Orientador: Prof. Dr. Antonio Augusto Coppi Maciel.

1. Bovinos clonados. 2. Estereologia. 3. Placenta. 4. Vilos coriônicos. Título. 


\section{UNIVERSIDADE DE SÃO PAULO \\ Faculdade de Medicina Veterinária e Zootecnia}

Comissão de Bioética

\section{$P A R E C E R$}

Interessado: Procássia Maria de Oliveira Lacerda

Assunto: Protocolo de experimentação adotado em experimento animal.

A Comissão de Bioética da Faculdade de Medicina Veterinária e Zootecnia da Universidade de São Paulo, após analisar o projeto já executado e protocolado sob o número 874/2006, intitulado: “Estudo comparativo e quantitativo do vilo coriônico da placenta de bovinos clonados e não clonados", no qual foram utilizados 04 (quatro) bovinos (placenta), sob responsabilidade do Prof. Dr. Antonio Augusto Coppi Maciel Ribeiro, constatou que o mesmo foi realizado de acordo com os princípios de bioética, adotados por esta Comissão.

São Paulo, 22 de março de 2006

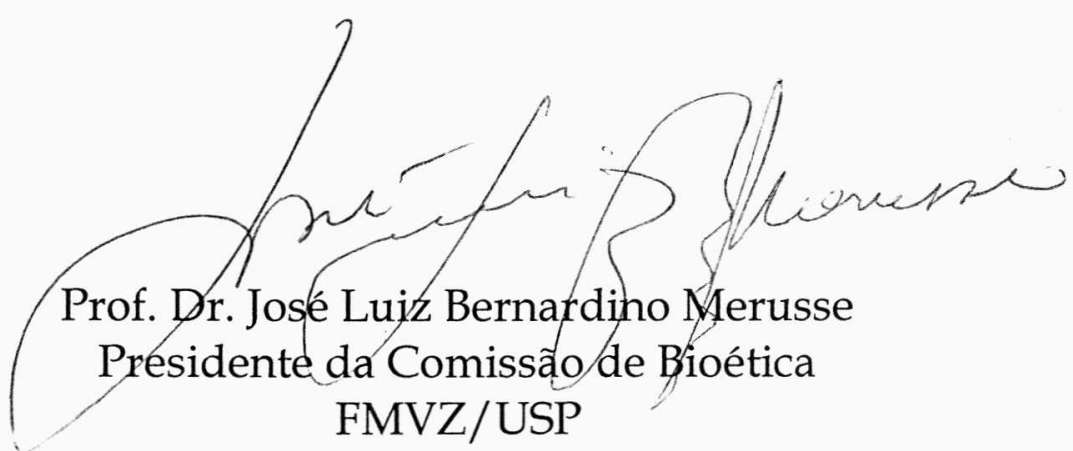




\section{FOLHA DE AVALIAÇÃO}

Nome : LACERDA, Procássia Maria de Oliveira

Título: Aspectos estereológicos dos vilos coriônicos da placenta de bovinos clonados

Dissertação apresentada ao Programa de Pósgraduação em Anatomia dos Animais Domésticos e Silvestres da Faculdade de Medicina Veterinária e Zootecnia da Universidade de São Paulo para obtenção do título de Mestre em Ciências.

Data:

Banca Examinadora

Prof. Dr.

Instituição:

Assinatura:

Julgamento:

Prof. Dr.

Instituição:

Assinatura:

Julgamento:

Prof. Dr.

Instituição:

Assinatura:

Julgamento: 
Quem é o homem que teve o poder de andar sobre o mar?

Quem é Ele que pode fazer o mar se calar?

No momento em que a tempestade vier te afogar,

Ele vem com toda autoridade e manda acalmar.

Quem é o homem que teve o poder de fazer Israel

Caminhar por entre as águas do Mar Vermelho.

Fez caminho no meio do mar para o povo de Israel passar.

Do outro lado com os pés enxutos puderam cantar:

\section{o Hino da vitória}

Quando estiver frente ao mar e não puder atravessar

Chame este homem com fé só Ele abre o mar.

Não tenha medo irmão se atrás vem faraó

Deus vai te atravessar e você vai entoar

\section{O Hino da vitória}

Toda vez que o Mar Vermelho tiver que passar,

Chame logo este homem para te ajudar.

É nas horas mais difíceis que Ele mais te ver,

Pode chamar este homem que Ele tem poder.

Se passares pelo fogo não vai te queimar.

Se nas águas tu passares não vão te afogar.

Faça como Israel que o mar atravessou

E no nome do Senhor

\section{O Hino de Vitória}

Do outro lado cantou. 
Aos que foram capazes de dizer não quando eu queria o sim, aos que me deixaram chorar quando eu errei, aos que me fizeram fazer a lição quando eu queria brincar, aos que não me deram o que eu queria, mas me deram o que eu precisava. Aos que me ensinaram a importância do não, o significado das lágrimas, a necessidade do estudo e o valor da vida... Tudo o que sou agradeço a vocês, meus pais, sem vocês eu não teria aprendido a viver e não teria suportado a ausência nesses anos de batalha. Obrigada por me fazerem acreditar que sonhos são possíveis e que as dificuldades fazem parte do nosso amadurecimento. Podemos vencer todas as barreiras pelo amor... 
dedico.

Aos meus irmãos,

\section{Lacôncia, Estórlace e Ana Angélica Lacerda}

Por serem os mais amorosos irmãos que alguém poderia ter, que sempre apoiaram meus sonhos, sempre acreditaram em mim e mesmo longe nunca me deixaram sozinha, sempre estavam presentes, mesmo que as lágrimas da saudade fossem muitas vezes inevitáveis. A vocês meus amados, pelo carinho, amor e apoio.

dedico. 
A minha Cunhada

Shirley Maclayne Lacerda

Por ser a mais especial de todas as cunhadas, pela amizade, pelo apoio espiritual, pela conversas demoradas ao telefone, pela sua presença em todas as etapas da minha vida, desde o primário até hoje, pós-graduação. A você minha amigona, também dedico. 
Aos Meus sobrinhos

Estilrem, Samersom, Suandre e Isabele Lacerda

Por serem os amorzinhos de titia, que mesmo sem entender muito, perguntam onde estou, quando eu vou voltar, se preocupam comigo, querem saber o porquê de tudo...Mas a que ainda não conheci (Isabele)sei que me ama, pois a amo desde que soube que estava sendo gerada, e nossa família é marcada pelo amor, senão fosse não conseguia está tanto tempo longe.A vocês meus pequenos grandes amores, dedico. 
Ao meu mestre,

\section{José Fernando Gomes de Albuquerque,}

Por ter feito eu me apaixonar pela anatomia a tal ponto de quase deixar passar o que eu amava. Por ser mais que um professor, um paizão...Por ter um dos corações mais lindos que já conheci...Por mostrar que amizades profundas e verdadeiras podem existir entre mestres e discípulos...Por confiar em mim, por acreditar que eu conseguiria.

AO MESTRE, COM CARINHO,

dedico. 


\section{Agradecimentos}

Por tudo que és, por tudo que tens feito.

Tua presença e direção.

Minha vida transforma por tua graça e poder

És muito além do que eu posso entender.

\section{Obrigado Senhor,}

Graças te dou, todos os dias, Graças te dou por tudo que me faz viver.

Pela família, por toda cura, pela conquista de tuas promessas.

Pelo teu grande amor por mim.

(Graças te damos, Renascer Prise VII)

Á Faculdade de Medicina Veterinária e Zootecnia da Universidade de São Paulo, por proporcionar uma oportunidade ímpar de desenvolvimento técnico, científico, profissional e pessoal.

Á Fundação de Amparo a Pesquisa do Estado de São Paulo - FAPESP, processo n$^{\circ}$. 04/04045-0, por acreditar no nosso projeto apoiando financeiramente o desenvolvimento desta pesquisa.

Ao meu orientador, Antonio Augusto Coppi Maciel Ribeiro, por me mostrar o que é pesquisar com seriedade e como é ser um orientador dedicado, você é o meu exemplo de pesquisador. Sou muito grata a Deus por tê-lo colocado em meu caminho, pois aprendi muito ao seu lado. Obrigada pelas horas analisado comigo todos os cálculos, pelos inúmeros "rabiscos" de correções, pela preocupação em fazer o melhor. A você Guto, agradeço.

A professora, Maria Angélica Miglino, pela confiança, pela oportunidade de trabalhar ao seu lado mesmo não me conhecendo. Obrigada professora por me mostrar que devemos ser ousadas, e ter atitude. O seu exemplo de mulher que faz, ficou marcado na minha memória. Obrigada.

Ao Prof. Dr. Terry Mayhew (University of Nottingham, Nottinghan, Uk) pelo profissionalismo, seriedade e dedicação desprendida ao fazer sugestões nas análises dos resultados deste trabalho.

Ao Prof. Dr. Julio César de Carvalho Baliero, pela forma atenciosa com que fez todas as análises estatísticas, sem medir esforços em me ajudar na corrida contra o relógio. 
Aos Profs.(a). Drs.(a). Francisco Javier H. Blasquez, José Roberto Kfoury, Paula de Carvalho Papa, Pedro Primo Bombonato, José Manoel, pelo carinho, aprendizado e apoio.

Ao Prof. Flávio Vieira Meirelles pela amizade, pela cooperação e apoio na realização deste trabalho e por aceitar o convite de participar da minha banca.

Ao meu cunhado Jeferson Santos e meu futuro cunhado Marcelino, pela força e amizade, por todos os momentos que estivemos juntos, vocês são maravilhosos.

A minha irmãzinha Vivian Vargas de Moraes, por realmente ser aquela que sempre me fez saber que eu tenho uma família aqui em São Paulo; que sempre se preocupou em não me deixar sozinha e por compartilhar comigo seu lindo presente, sua própria família, que agora também é minha. A vocês, Arie Vitor de Moraes e Edith Vargas de Moraes, que me ajudaram a diminuir a ausência de meus pais, me amando como filha. Amo todos vocês....Muito Obrigada.

A minha amiga Cristiane Naoko Takamine, por tudo que vivemos juntas, pelos anos de convivência, por todos os momentos de descontração, pelas muitas conversas que rolavam a madrugada. A você amiga, eu agradeço. Obrigada por tudo.

A minha amiga Josy Alvarenga Cal, e a sua mãe maravilhosa Sônia Alvarenga, por terem conquistado meu coração. Hoje posso dizer que vocês já se tornaram necessárias na minha vida. Obrigada pelas orações, pelo aprendizado mútuo, pelas conversas abençoadas.... A vocês, agradeço.

A equipe maravilhosa do LSCA (Laboratory Stereology and Chemical Anatomy) Ana Rita de Lima, Emerson Fioretto, Fernando Ladd e Aline Ladd (faz parte indiretamente do laboratório...risos), Silvio Pires Gomes, Taís Sasahara, Victor Hugo Rodrigues e Wanderley Guidi, por todos os momentos que vivemos juntos, dentro e fora do laboratório,nos tornamos mais que companheiros de trabalho, mas amigos para vida toda. Cada um em particular tem um lugar especial no meu coração, agradeço a Deus a oportunidade de conviver com vocês esse tempo... A todos meu muito obrigada.

A minha Pastora Salete, por ser o meu apoio e meu suporte espiritual, por ser além do eu esperava de uma pastora, por ser meu ideal de mulher, fiel, sábia, determinada, cheia de poder e unção... Obrigada por me ajudar a chegar até aqui, você sabe que essa vitória também é sua... Cheguei pastora, cheguei!!!! Nada me deteve.... Brigadão minha linda!!

A minha amigona Tilde Froes, que foi um presente de Deus, uma pessoa que chegou e ficou. Você é uma benção, os momentos que desfrutamos juntas com a pastora foram tudo de bom, de muito riso... Obrigada por ter me proporcionado as melhores gargalhadas aqui em São Paulo. Só você mesmo!!! HÁ!!! Brigadão amiga!!! 
Aos meus amigos de pós-graduação, Dulcinéa Gonçalves, Fernando Garbelotti, káterin Grondona, David Iturrizaga, Camila Trevisan, Flávio Ribeiro, Ricardo Romão, pelo carinho, amizade e convivência em todo esse tempo. Valeu mesmo!!!!!

Aos demais amigos da pós-graduação, dos mais antigos aos mais recentes, todos eu considero como parte integrante da minha história aqui na Anatomia, pois de uma forma direta ou indiretamente fizeram parte da minha vida... Um beijão a todos, Obrigada.

A equipe maravilhosa que sempre estava presente nos nascimentos dos clones: Prof. Bírgel Junior, Profa. Kíki, José Rodrigo, Alemão, Fernando, Felipe, Moisés, Elisa, João Paulo, Fábio, Yuri e o casal atencioso João e Maria... Pela amizade, pelo apoio no meu trabalho, por tudo que vivemos em cada nascimento, pois cada um era uma surpresa diferente. A vocês, obrigada.

Aos meus amigos Flávia Verechia e Antonio Assis Neto, por terem me recebido em sua casa com muito carinho no tempo de coleta, me senti amada por vocês. Obrigada por tudo. Sabemos que podemos contar um com o outro. Valeu mesmo!!!

Aos alunos de Iniciação científica, André Gonçalves, Cauê Toscano, Renato Cavalcante e Samanta Melo, pelos períodos que compartilhados no laboratório, pelas brincadeiras e risadas ...não é mesmo Cauê e Renato??? Risos... A vocês os meus agradecimentos.

A turma da sala 12, Cauê, Carlos Ambrósio (Caju), Daniele, Adriana Morini, Érika Branco; Marcelo (Ubatuba), Rosa, Tatiana Carlesso, Vivian Samoto, pela convivência, amizade, relatório CAPES, pizzas, etc ...risos...Foi muito bom está junto com vocês no meu tempo de sala 12. Realmente, inesquecível!!!!

Aos meus amigos de Mossoró que também estão fazendo pós aqui em Sampa, Carlos Eduardo (Caduzinho), Barreto Junior, Genilson Queiroz e Valéria Veras, pela longa amizade, por tudo que vocês significam para mim, sei que posso contar com vocês. Obrigada!!!!!

Aos amados da minha igreja Renascer em Cristo, em especial o meu grupo de R12, Fátima, Silvia, Robson, Patrícia, Karina, Rogério, Ione, Edina, Edilene, Júlia... Por orarem por mim e por estarem sempre prontos para me ajudar no que precisasse. A vocês, preciosos de Deus, meu muito obrigada.

Aos funcionários da FMVZ- USP, pela atenção, respeito, consideração e por me ajudar sempre que precisei, em especial Maicon, Jackeline, Edinaldo (Índio), Diogo, Ronaldo, João, Raimundo, Natália (Branca), Antonio Rodrigues, Helena Tanganine. Obrigada. 


\section{RESUMO}

LACERDA, P. M. O. Aspectos estereológicos dos vilos coriônicos da placenta de bovinos clonados. [Stereological aspects of chorionic villi of the placental of cloned bovines]. 2006. 77p. Dissertação (Mestrado em Ciências) - Faculdade de Medicina Veterinária e Zootecnia, Universidade de São Paulo, São Paulo, 2006.

A clonagem de animais é uma técnica em desenvolvimento e ainda requer refinamento, uma vez que as perdas embrionárias são significativas. Mesmo com animais chegando à termo, algumas deficiências verificadas ao nascimento provocam a morte destes antes do primeiro mês de vida. As alterações placentárias durante a embriogênese estão relacionadas, à formação deficiente da placenta, principalmente nas regiões de troca materno-fetal. Considerando a necessidade de estudos mais detalhados sobre a morfologia da placenta e a ausência de estudos quantitativos das estruturas placentárias em grandes mamíferos, investigamos comparativamente os vilos coriônicos da placenta de bovinos não clonados e clonados usando delineamento estereológico. Foram utilizadas placentas de quatro fêmeas de bovinos clonados e quatro de não clonados. A amostragem foi realizada de modo uniforme, sistemático e aleatório, sendo obtidas estimativas de densidade de volume, volume referência, tamanho e comprimento e número de unidades volume star. Todos os parâmetros estereológicos apresentaram valores superiores (embora não significativos) para não clonados, com exceção do número de unidades volume star. No entanto, a placenta de não clonados foi mais eficiente $(\mathrm{p}=0.014)$. Apesar de não significativos, os resultados sugerem a existência de diferenças biológicas, ou seja, a placenta de bovinos não clonados apresenta vilos maiores (porém em menor número), mas distribuídos em um número maior de placentomas. Já em animais clonados, estes vilos são menores, mais numerosos e distribuídos em um número menor de placentomas.

Palavras-chave: Bovinos clonados. Placenta. Vilos coriônicos. Estereologia. 


\begin{abstract}
LACERDA, P. M. O. Stereological aspects of chorionic villi of the placental of cloned bovines [Aspectos estereológicos dos vilos coriônicos da placenta de bovinos clonados.]. 2006. 77p. Dissertação (Mestrado em Ciências) - Faculdade de Medicina Veterinária e Zootecnia, Universidade de São Paulo, São Paulo, 2006.
\end{abstract}

Animal cloning is still in development it requires further improvements since embryonic losses are remarkable animals die before the first month after birth. The placental changes during embryogenesis cause a deficiency in the placenta, mostly in the maternal-fetal exchange areas. Due to the need for more detailed studies on the placenta's morphology, especially the quantitative analysis of the placenta structures in large animals, chorionic villi were comparatively investigated in both cloned and non-cloned bovines by means of stereology designed methods. Placentas from four cloned and four non-cloned bovines were used. Specimens were collected in a random uniformand systematic procedure, and stereological designed methods were pursued to estimate volume density of villi; the volume reference of placenta (Cavilieri Principle), surface density, surface area, star volume and number of star volume units. All parameters presented larger values for non-cloned, with exception of number of star volume units, thought these results were statistically nonsignificant larger in non-cloned animals $(\mathrm{p}=0.014)$. In conclusion, it is possible to say that there are biological differences, in the placenta of non-cloned bovines which presents larger chorionic villi, small villi number, but distributed in a larger number of placentomas. In cloned bovines, however, villi are smaller, numerous more, and they are distributed in fewer number of placentomes.

Key words: Cloned Bovine. Placenta. Chorionic villi. Stereology 


\section{SUMÁRIO}

1 INTRODUÇÃO

2 REVISÃO DE LITERATURA …………………............................. 23

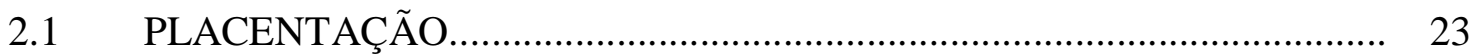

2.1.1 Placentação de Mamíferos....................................................................... 23

2.1.2 Placentação em Ruminantes................................................................ 24

2.2 ESTRUTURAS PLACENTÁRIAS NOS RUMINANTES........................... 25

2.2.1 Membranas Fetais............................................................................ 25

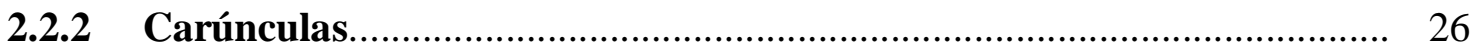

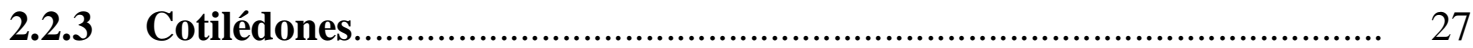

2.2.4 Placentoma

2.2.5 Vilos Coriônicos............................................................................. 34

2.2.6 Hematoma Placetário........................................................................... 37

2.3 PLACENTAÇÃO EM BOVINOS CLONADOS...................................... 38

2.4 ASPECTOS QUANTITATIVOS DA PLACENTA................................... 40

3 MATERIAL E MÉTODOS................................................................. 42

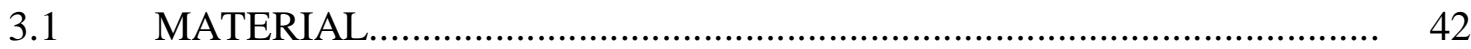

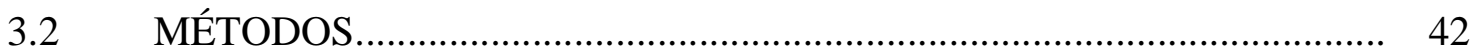

3.2.1 Microscopia de Luz de Cortes Semi-finos.................................................. 43

3.2.2 Estudo Esteriológico............................................................................... 43

3.2.2.1 Amostragem dos Campos Histológicos..................................................... 45

3.2.2.2 Volume Referência do Placentoma (Princípio de Cavalieri, 1635)............ 45

3.2.2.3 Densidade de Volume "Volume Density" (Vv).......................................... 46

3.2.2.4 Volume Star (' Vstar)............................................................................. 46

3.2.2.5 Densidade de Superfície (Vv) ................................................................ 47

3.2.2.6 Área de Superfície (Sa).......................................................................... 47

3.2.2.7 Número de Unidades Volume Star $\left(\mathrm{N}^{-} \mathrm{Vstar}\right)$........................................... 47

3.2.3 Eficiência da Placenta............................................................................... 47

3.2.4 Análise Estatística.............................................................................. 48

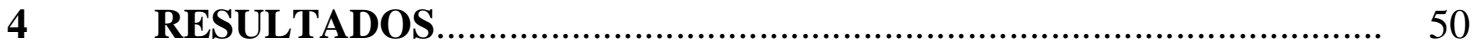

4.1 ASPECTOS MACROMORFOMÉTRICOS............................................. 50

$4.2 \quad$ ASPECTOS HISTOLÓGICOS............................................................. 51

4.3 ESTUDO ESTEREOLÓGICO.................................................................... 53 
EFICIÊNCIA PLACENTÁRIA.......................................................... 54

4.5 ANÁLISE DE CORRELAÇÃO............................................................ 54

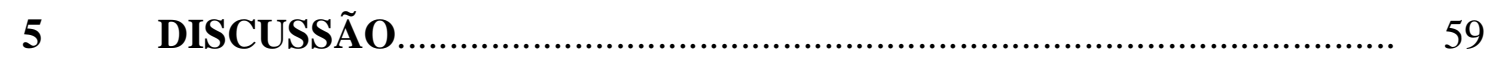

5.1 ASPECTOS MACROSCÓPICOS...................................................... 59

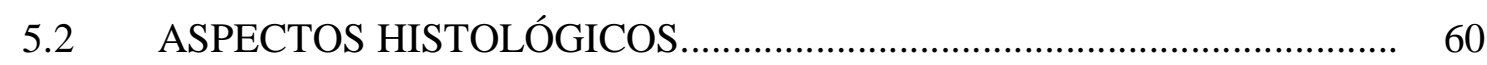

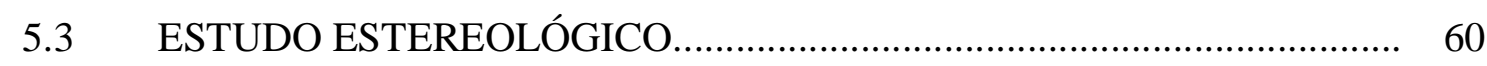

5.3.1 Volume Referência (Volume dos Placentomas e da Placenta)................ 61

5.3.2 Densidade de Volume dos Vilos Coriônicos........................................... 62

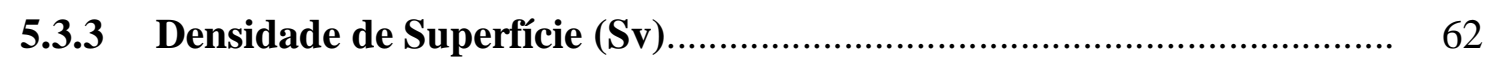

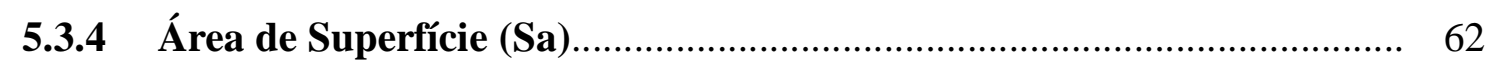

5.3.5 Volume Star e Número de Unidade Volume Star................................... 63

5.4 EFICIÊNCIA DA PLACENTA.............................................................. 64

5.5 CORRELAÇÃO ENTRE VOLUME DA PLACENTA E DEMAIS PARÂMETROS QUANTITATIVOS.................................................... 64

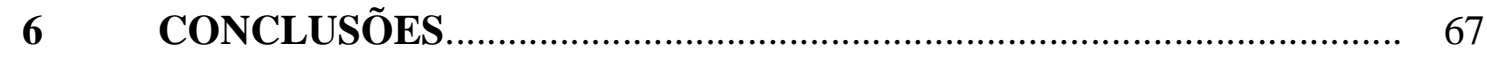

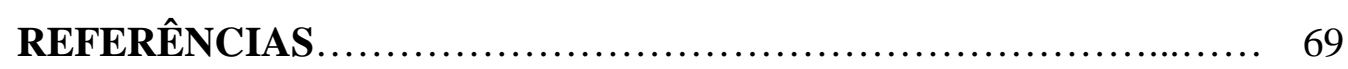


Introdução 


\section{INTRODUÇÃO}

Considerando a importância econômica dos bovinos na sociedade, criadores e pesquisadores têm procurado aprimorar o manejo desta espécie, a fim de obter uma maior eficiência produtiva por meio das biotecnologias da reprodução, que representa importante papel neste processo.

A biotecnologia de transferência nuclear ou reconstituição embrionária permite produzir cópias idênticas de indivíduos (clones), que a partir de uma melhor investigação e aprimoramento da técnica, proporcionará um avanço extraordinário no momento econômico mundial (BORDIGNON, 2001). No entanto, a produção de animais clonados ainda constituise um processo ineficiente, devido às altas taxas de mortalidade embrionária (HILL et al., 2001).

Esta mortalidade tem sido observada no estágio inicial e final da gestação, mas estudos indicam que a causa das perdas está associada a um desenvolvimento anormal da placenta (BORDIGNON, 2001; HILL et al., 2001; SCHLAFER, 2000).

A placenta de ruminantes é formada por placentomas, que são estruturas numerosas com tamanhos e formas muito variadas, são caracterizadas pela presença de um tufo de vilosidades fetais conhecida como cotilédones e por invaginações criptiformes reunidas no útero que são as carúnculas uterinas (PINTO, 2002).

A passagem e a troca de nutrientes da mãe para o feto são realizadas por meio dos vilos placentários (MAYHEW, 2002). Justamente nessas áreas dos vilos, nas regiões das trocas materno-fetais, é onde se tem observado uma diferença estrutural e morfológica significativa quando a placenta de animais clonados comparados aos animais não clonados.

As vilosidades placentárias apresentam-se das mais variadas formas dependendo da espécie animal considerada. Em bovinos assumem o aspecto de uma árvore cilíndrica constituída de um tronco principal que se ramifica progressivamente em vilos de ordens menos elevadas. Geralmente eles se encaixam em criptas correspondentes, onde os septos principais emitem septos secundários para formar o constituinte materno (PINTO, 2002). A função destas vilosidades é colocar os vasos fetais (alantóide) em proximidade com os vasos sanguíneos maternos (JAINUDEEN, 2005).

Devido à função das vilosidades na gestação é necessário um estudo detalhado destas estruturas, a fim de se verificar o que ocorre na área de troca materno-fetal durante o processo gestacional do animal clonado e não clonado, tendo em vista que problemas como abortos, má 
formação fetal, mortalidade ao nascimento, anormalidades de desenvolvimento, cotilédones hemorrágicos, estão relacionadas com a má formação placentária (HILL, 2001). Neste contexto, constitui-se o nosso objetivo geral estudar o comportamento desta estrutura em placentas de animais clonados e não clonados usando ferramentas estereológicas. Os objetivos específicos são: estimar a densidade de vilos "volume density"; estimar o tamanho dos vilos; estimar o tamanho dos placentomas; estimar o volume dos placentomas.

Estudos recentes têm mostrado que a clonagem ainda é um processo ineficiente (HILL et al., 2001) e que as anormalidades placentárias estão associadas com alta taxa de mortalidade nos programas de clonagem em mamíferos (HILL et al., 2000).

Do ponto de vista teórico, o estudo se justifica pela necessidade de assentar bases estereológicas que permitam fornecer dados indispensáveis ao estudo da fisiologia placentária em animais clonados e não clonados, considerando que o estudo estereológico desta estrutura ainda não foi realizado em bovinos. Mas na placenta humana podemos verificar que este assunto já está bem explorado (BURTON et al., 1989; BURTON et al., 1996; MAYHEW, 1986, MAYHEW, 1991; MAYHEW, 2001; MAYHEW, 2003; MAYHEW et al., 2004; MAYHEW; BARKER, 2001). Pretendemos desta forma, fornecer subsídios a pesquisadores interessados em estudar os aspectos quantitativos desta estrutura.

Do ponto de vista prático, espera-se que o estudo forneça elementos essenciais ao melhor entendimento das anormalidades placentárias, considerados como um dos causadores de morte fetal ou de anormalidades de crescimento no animal clonado, proporcionando desenvolvimentos científicos, econômicos e produtivos. 
Revisão de Literatura 


\section{REVISÃO DE LITERATURA}

A placenta é um órgão que mesmo com o passar dos séculos ainda desperta muita curiosidade. Antes de descrevermos este órgão, conheceremos um pouco sobre a origem do termo "placenta".

A placenta com suas membranas foram primeiramente chamadas no grego de deútera e posteriormente de secundina no latim. Mas o termo "placenta" derivou-se da palavra grega "plakoûta", que sugeria o nome dado a um bolo redondo da Grécia (plakous) (SKINNER, 1961). Em latim placenta também tinha a acepção de bolo chato (TORRINHA, 1942). No entanto, o nome da placenta só aparece na nomenclatura anatômica no século XVI, quando Realdus Columbus, discípulo de Vesalius, publica seu livro "De Re Anatômica" utilizando a expressão "in modum orbicularis placentae" que quer dizer "a modo de um bolo redondo", mas foi Fallopius entre 1523 a 1562 que empregou o termo "placenta uterina" (SKINNER, 1961). Esta denominação se sobrepôs à de secundina, passando a merecer a preferência dos anatomistas e obstetras.

\subsection{PLACENTAÇÃO}

A estrutura e classificação da placenta têm sido muito estudadas apresentando uma diversidade muito grande entre as espécies.

\subsubsection{Placentação de Mamíferos}

De acordo com os limites que separam os organismos materno e fetal (barreira-fetal), á placenta tem função de proteção contra a penetração de agentes nocivos (moléculas e microorganismos) para o organismo fetal, bem como o controle seletivo contra a penetração de outras substâncias (LEISER; KAUFMANN, 1994). A placenta no seu sentido restrito presume a existência de um córion fetal que se localiza diretamente sobre a mucosa materna. 
A placentação córion-alantoide dos mamíferos é classificada em quatro tipos, segundo a formação dos vilos coriônicos: placenta difusa, placenta zonária, placenta cotiledonar e placenta discoidal. Em ruminantes os cotilédones apresentam uma variação quanto ao número, forma, tamanho e estrutura conforme a espécie animal considerada (HAFEZ, 1954). Nos carnívoros a placenta é caracterizada como sendo do tipo endotelial (PERRY, 1981). Na cadela ela é classificada como verdadeira e pertencente aos animais decíduos (SANTOS, 1996), ou seja, animas cuja união materno fetal é íntima, ocorrendo desprendimento do endométrio no momento do parto. Zonária (STOFFEL et al., 1998) por apresentar um formato de cinta circunscrita a uma zona delimitada. No gato doméstico ela foi descrita como córioalantoide e zonária (LEISER; KOOB, 1993).

Em roedores há uma variação muito grande na classificação desta estrutura. Ela é considerada de labiríntica e hemocorial (MOSSMAN; STRAUSS, 1963), discoidal e hemomonocorial (KAUFMANN, 1981) e cório-alantoidiana (KING, 1982) em cobaias. Nos roedores silvestres a variação é ainda mais significativa, por exemplo, placenta da capivara ela é classificada como do tipo hemocorial (BARBELLA, 1987; LOPÉZ, 1981) e córioalantoidiana, discóide e labiríntica (SOIRON, 1993) A do porquinho da índia é do tipo discoidal e hemo-monocorial (KAUFMANN, 1981). Na paca a placenta também é discoidal, mas do tipo hemocorial (MATAMOROS, 1981).

\subsubsection{Placentação em Ruminantes}

A placenta de ruminantes é caracterizada como cotiledonária ou múltipla devido à presença de carúnculas endometriais, que são espessamentos do tecido sub-epitelial do útero, presentes mesmo em vacas não gestantes. Durante a gestação, estas carúnculas formam conexões com proliferações do córion. Os grupos de vilos coriônicos formam os cotilédones que junto com as carúnculas formam as unidades funcionais denominadas placentomas. Estes variam em número nas diferentes espécies de ruminantes, sendo 70 a 142 na vaca .

A placenta dos ruminantes foi incluída na categoria sindesmocorial devido à perda do epitélio uterino materno, fazendo com que o cório esteja em contato com um sincício materno-fetal e não com tecido conjuntivo (AMOROSO, 1952). No entanto, o termo mais apropriado seria sinepiteliocorial, devido o resultado da migração e fusão das células binucleadas do trofoblasto com as células do epitélio uterino (WOODING, 1992). 
As placentas dos bovinos são classificadas como zonária, cotiledonária, caracterizada por muitas unidades placentárias denominadas cotilédones, que se interagem com unidades maternas, formando os placentomas, os quais são separados por áreas intercotiledonárias de cório liso (LEISER; KAUFMANN, 1994).

A placenta de ruminante também é tida como placentomatosa (NODEN; DE LAHUNTA, 1990) ou múltipla (STEVEN, 1975) isso por que apenas certos pontos de contato são estabelecidos para a transferência hemotrófica. Os locais de troca hemotrófica são denominados de placentomas (LATSHAW, 1987).

Em placentas de bovinos o formato dos cotilédones pode ser: circular, elíptico ou quadrangular, sendo a maioria ovóide e alguns reniformes, onde em alguns casos há fusão de cotilédones vizinhos em diversos graus (MIGLINO, 1991).

\subsection{ESTRUTURAS PLACENTÁRIAS NOS RUMINANTES}

As estruturas placentárias dos ruminantes foram separadas por tópicos para facilitar a descrição de cada uma delas.

\subsubsection{Membranas Fetais}

A placentação nos ruminantes envolve uma adesão generalizada do córion com o epitélio uterino e, mais adiante, modificações nas interfaces carunculares e cotiledonárias para formar os placentomas. O formato do córion é o mesmo da matriz, ou seja, ele invade o corpo e os dois cornos uterinos. No corno uterino grávido seu desenvolvimento é maior do que no corno não gravídico, e a distinção do corpo e dos cornos se torna difícil. Quando a gestação é gemelar, os dois cornos se desenvolvem paralelamente, contendo um feto cada um. Neste caso, os dois podem estar isolados por dois córions independentes. A face externa do córion relaciona-se com a mucosa uterina formando a placenta (KING; ATKINSON, 1987).

$\mathrm{Na}$ maioria dos ruminantes, o córion forma árvores vilosas as quais adapta-se aos correspondentes tecidos maternos, isso ocorre na placentação tipo vilosa (LEISER; KAUFMANN, 1994). O epitélio coriônico é constituído por uma única camada celular, mas 
nos estágios precoces de desenvolvimento embrionário, as células trofoblásticas são de dois tipos diferentes, células principais ou uninucleadas e células binucleadas (STEVEN, 1984). Na prenhez avançada o córion aparece altamente vascularizado e mostra desenvolvimento de numerosos vilos. No parto a linha da separação placentária está entre a base do epitélio coriônico e está abaixo da membrana basal.

Nos bovinos o alantóide cresce junto com o córion para formar o alanto-córion classificando a placenta córion-alantoidiana. A placenta de ruminantes é do tipo epitéliocorial, onde o córion do feto está em contato direto com o epitélio do útero (FRANDSON, 1986). Essas áreas de relacionamento assemelham-se a cogumelos e são denominadas de carúnculas. A superfície externa do córion-alantóide da placenta da vaca é recoberta por vários cotilédones que se unem ás carúnculas do útero para formar os placentomas (SLOSS; DUFTY, 1980). A área do córion liso é caracterizada pela ausência de vilosidades (BJORKMAN, 1954).

\subsubsection{Carúnculas}

As carúnculas endometriais são características de placentas de ruminantes e são caracterizadas pelo espessamento do tecido sub-epitelial do útero, presentes mesmo em vacas não gestantes. Durante a gestação, estas carúnculas formam conexões com proliferações do córion (MARSHALL, 1952). As carúnculas são convexas nas vacas e côncavas na ovelha e na cabra. No inicio da gestação elas se apresentam lisas enquanto que na metade e final de gestação apresentam aspecto esponjoso devido à formação de inúmeras criptas semelhantes a favo-de-mel (RAM; CHANDRA, 1984).

Nas búfalas prenhes, as carúnculas são arranjadas linearmente, distribuídas em cinco ou seis fileiras no corpo do útero e duas nas extremidades (HAFEZ, 1955). No entanto, ao comparar placentas bovinas com bufalinas, observou-se que nos bovinos as carúnculas estão arranjadas em 4 fileiras longitudinais em cada corno uterino, duas fileiras apresentam-se paralelas à margem de inserção do mesométrio e duas são paralelas à margem antimesometrial, onde as carúnculas no útero gestante são ovais com o eixo longitudinal em posição perpendicular ao eixo longitudinal do corno uterino, nas búfalas as carúnculas também estão arranjadas em 4 fileiras em cada corno, duas mesometriais e duas antimesometriais, mas em alguns casos observou-se um pequeno número de carúnculas 
arranjadas numa quinta fileira no terço médio do corno uterino (ABDEL-RAOUF; BADAWI, 1966; SILVA, 2004), diferindo do número de 5 ou 6 fileiras citado anteriormente (HAFEZ, 1955). A forma das carúnculas dos bufalinos também é variada e em geral apresenta a forma oval. As formas irregulares observadas são principalmente devido à fusão de uma ou mais carúnculas vizinhas. Esta fusão de carúnculas também é observada nos bovinos, e ocorre mais no terço médio do corno onde as estruturas estão mais próximas.

O número de carúnculas uterinas em bovinos pode apresentar variações que vão desde 50 até 180 carúnculas por gestação, nas fêmeas multíparas desenvolvem pequenas carúnculas que foram observadas em gestações anteriores (MIGLINO, 1991; PAVAX, 1983).

Embora o útero apresente a formação de carúnculas é interessante lembrar que nem todas as carúnculas formam placentomas durante a gestação, nas ovelhas, por exemplo, apenas 70 a $80 \%$ das carúnculas participam da placentação, embora haja esta redução no número de carúnculas ela é compensada pelo aumento do tamanho dos placentomas existentes possibilitando a eficiência na troca de nutrientes (HRADECKY et al., 1988).

Topograficamente, na placenta dos bovinos, as criptas das carúnculas nas quais os vilos se estendem, são revestidas por um epitélio cúbico simples de origem materna. $\mathrm{O}$ epitélio pode ser, eventualmente, incompleto ou estar ausente no septo materno da carúncula. O número de células maternas nas criptas das carúnculas da cabra não se mostrou elevado e permaneceu estável ao longo da gestação, fato contrário ao observado em vacas quando este número decrescia muito à medida que o parto se aproximava, aparentemente, o decréscimo destas células maternas nas criptas das carúnculas também é importante para a liberação da placenta, mas é provável que não seja o único mecanismo relacionado (MARQUES JUNIOR et al., 1992).

\subsubsection{Cotilédones}

Os cotilédones são estruturas fetais que se fundem com as carúnculas ou projeções especializadas da mucosa uterina para formar os placentomas ou unidades funcionais, embora os maiores sítios para a formação dos placentomas sejam as carúnculas, é possível ocorrerem placentomas acessórios nas áreas intercarunculares (HAFEZ, 1982). O cotilédone nos ruminantes penetra no sistema septal materno da carúncula endometrial, e juntos formam os numerosos placentomas (LEISER et al., 1997b). 
Os cotilédones apresentam uma variação quanto ao número, forma, tamanho e estrutura, conforme a espécie animal considerada (JENKINSON, 1925). Na vaca os cotilédones possuem forma ovóide, com enormes tufos de vilos oriundos do cório fetal, que se engrenam nos receptáculos maternos, são muito ramificados e se adaptam em criptas de tamanho corresponde, onde o total de agregação das criptas para recepção dos vilos de um único cotilédone, termina nas criptas maternas (DRIEUX; THIÉRY 1951). Os pontos na parede do útero onde estes cotilédones maternos serão formados são predeterminados e reconhecidos com áreas elevadas (carúnculas cotiledonárias antes da gestação) que podem ser vistas de fato no útero da vaca (JENKINSON, 1925). Na placenta de búflas o formato dos cotilédones varia entre circular, elíptico ou quadrangular e ainda a formato ovóide e reniforme, em alguns casos há fusão de cotilédones vizinhos em diversos graus (FEITOSAJÚNIOR, 1997).

Durante a prenhez aumenta a vascularização dos cotilédones maternos e fetais e nas extremidades intercotiledonárias, sendo que nos estágios precoces de prenhez não há contato próximo entre as membranas e os cotilédones maternos, mas com o avanço da prenhez, os vilos aparecem na superfície da membrana coriônica e posteriormente os cotilédones fetais estão visivelmente arranjados em fileiras (HAFEZ, 1954).

Quanto ao número de cotilédones na vaca, estes variam de 70 a 142 cotilédones, caracterizando este animal como policotiledonário (AMOROSO, 1952). O número de cotilédone do corno gestante na vaca é maior que no outro, às vezes até $150 \%$ a mais (MARSHALL, 1952). As búfalas apresentam um número superior de cotilédone que as vacas, com média de 124 cotilédones por placenta, sendo 74 no corno gestante e 50 no corno não gestante, em vacas o número médio de cotilédone foi de 95 , onde 56 encontravam-se no corno gestante e 39 no corno não gestante (BROSREKAR; SHARMA, 1972). Em outro estudo com 106 placentas de búfalas o número médio de cotilédones observados foi de 119,76 com um mínimo de 49 e um máximo de 217 cotilédones (SHARMA et al., 1979). Com uma amostragem menor de placentas o número de cotilédones apresenta nova variação, ou seja, em outras 34 placentas de búfalas o número médio de cotilédones observados foi de 92 por placenta, com máximo de 133 e um mínimo de 64, sendo a média de cotilédones no corno gestante (62 cotilédones) maior que no não gestante (30 cotilédones) (FEITOSA JUNIOR, 1997).

Em membranas fetais de 52 vacas da raça Hereford, a média de cotilédones nessa raça foi de 74 cotilédones, com um mínimo de 39 e um máximo de 108 cotilédones por placenta. Considerando a média de 74 cotilédones, 46 encontravam-se no corno gestante e 28 no corno 
não gestante, sendo o mínimo de 0 (zero) e o máximo de 50 nesse corno (DUFTY, 1974). Em placenta de Bos taurus, a quantidade média de cotilédones por placenta é de 88 com mínimo de 54 e máximo de 147, sendo que desse total 65 (40-103) foram encontrados no corno gestante e 27 (6-92) no corno não gestante (MIGLINO, 1991).

Ao pesquisar a placenta de vacas indianas Kadu e Kaikini (1974) classificaram os cotilédones em pequenos, médios e grandes, observando que a média de cotilédones pequenos é de 16,50 (31,92\%) no corno gestante e de 17,52 (57,33\%) no corno não gestante. A média no corno gestante de cotilédones médios é de 16,80 (32,48\%) e de 11,45 (37048\%) no corno não gestante, e nos cotilédones grandes a média foi de 18,41 $\pm 0,75(35,60 \%)$ no corno gestante e no corno não gestante de 1,58 (5,19\%). Purbey \& Sane (1977) também classificaram os cotilédones em pequenos, médios e grandes ao estudar a placenta de 6 vacas zebuínas da raça Dangi. Sendo que estes autores realizaram as medições destes cotilédones, a média encontrada de $6,94 \mathrm{~cm}(5,1-10,0 \mathrm{~cm})$ caracterizou os cotilédones grandes, a média de 4,06 cm $(2,7$ - 5,0) os cotilédones médios e os cotilédones pequenos apresentaram comprimento médio de $1,85 \mathrm{~cm}(1,2-02,4 \mathrm{~cm})$. No corno não gestante os tamanhos correspondentes são: $5,94 \mathrm{~cm}(5,1-7,4 \mathrm{~cm}) ; 3,7 \mathrm{~cm}(2,5-4,9 \mathrm{~cm})$ e $2,0 \mathrm{~cm}(1,0-2,4 \mathrm{~cm})$. Sharma et al. (1983) ao estudar a morfologia das membranas fetais de búfalas da raça Murrah afirmam que o número médio de cotilédones grandes, médios e pequenos é de 13, 58, 50, 72 e 55,12, respectivamente. Feitosa Junior (1997) ao classificar os cotilédones da placenta de 34 búfalas quanto ao tamanho obtém os seguintes resultados: pequenos, são os menores de $1 \mathrm{~cm}$, médios, são os que estão entre 1 e $4 \mathrm{~cm}$ e grandes são os maiores de $4 \mathrm{~cm}$, sob esse critério o autor concluiu que os grandes cotilédones predominam no corno gestante e os médios no corno não gestante desses animais.

Sharma et al. (1979) mencionam que somente 10 membranas fetais das 106 placentas de búfula da raça Murrah examinadas apresentam cotilédones acessórios, estas estruturas são observadas na área intercotiledonária formando pequenas elevações alongadas. Sharma et al. (1982) ao estudar a formação destes cotilédones acessórios verificaram que eles são pequenos e menos freqüentes, ou seja, são encontrados em cerca de 1,6\% das placentas examinadas. Eles formam pequenos botões espalhados sobre uma grande área, às vezes ocupam o lugar de cotilédones verdadeiros e todos são mantidos até o final da gestação. Esses mesmos autores também afirmam que na vaca a presença de numerosos e extensos cotilédones acessórios prejudica a prenhes.

Ao estudar a placenta de Bos taurus Miglino (1991) observou que os cotilédones distribuem-se de forma linear em 2 fileiras de cada lado da implantação do pedículo umbilical 
no hilo da placenta, onde a partir do $3^{\circ}$ mês de gestação há um aumento do número médio de cotilédones, o corno gestante apresenta um número maior de cotilédone em 97,5\% dos casos. Feitosa Junior (1997) ao estudar a placenta de 34 búfalas verificou o mesmo arranjo linear dos cotilédones organizado em 4 fileiras, duas de cada lado do pedículo umbilical, na maioria das vezes apresentam formato ovóide, alguns estão em fase de fusão e outros, de tamanho pequeno, estão agrupados em cachos, onde estes cotilédones agrupados em cachos são considerados como cotilédones de tamanho médio. Ainda segundo este autor o número médio de cotilédones aumenta de 70 entre o $5^{\circ}$ e $6^{\circ}$ mês de gestação até 99 no $10^{\circ}$ mês de gestação, complementando o observado por Miglino (1991). O número, bem como o diâmetro e a altura dos cotilédones variam de acordo com o estágio de prenhez e posição no útero (HAFEZ, 1955).

\subsubsection{Placentoma}

A superfície externa do corioalantóide da placenta da vaca é recoberta por vários cotilédones que se unem às carúnculas do útero para formar os placentoma (SLOSS; DUFTY, 1980). O Placentoma é a unidade funcional formada pelo cotilédone fetal e pela carúncula materna (NODEN; DE LAHUNTA, 1990), e é composto por uma parte materna e uma fetal, as quais estão fundidas para constituir um órgão de troca fisiológica entre a mãe e a prole (BJORKMAN; SOLLEN, 1960). Esta estrutura apresenta um aspecto tortuoso e irregular que pode ser bem conhecida ao corte devida o grande desenvolvimento que adquirem nas ramificações das vilosidades cotiledonárias.

Segundo Roberts (1986) somente uma parte da placenta materna, a das carúnculas endometriais e parte do alantocórion ou cotilédones, que se unem estreitamente para formar o placentoma, participam das funções placentárias.

Os primeiros placentomas a se desenvolverem são os da região do embrião e depois os placentomas localizados em direção à extremidade dos cornos, conforme as necessidades do feto (KINGMAN, 1948). O tecido materno estabelece uma íntima relação com o córion no labirinto intricado do placentoma, formando assim uma grande superfície de contato para os processos de troca que aí se realizam (SCHWARZE et al., 1970). Nas primeiras fases de formação do placentoma, o epitélio uterino e o tecido conjuntivo adjacente são destruídos e os fragmentos celulares são internalizados pelo córion, nesta fase da gestação, pigmentos típicos 
das células do epitélio são encontrados nas células binucleadas e outras células do trofoblasto (WINSATT, 1980). Os placentomas das placentas cotiledonárias tem pregas marginais do corioalantóide cobertas com citotrofoblasto que absorve obviamente as secreções das glândulas endometriais grandes, abrindo-se ao redor da base dos pedúnculos carunculares, uma configuração relatada para a forma de carúnculas côncavas.

Na placenta de caprinos e ovinos os placentomas são muito vascularizados pelos vasos maternos e fetais constituindo as principais áreas de troca placentária, onde a artéria fetal entra no placentoma pela depressão central do lado fetal e ramifica-se em artérias menores, as quais estão localizadas no centro dos vilos fetais (DANTZER et al., 1988).

$\mathrm{Na}$ vaca os placentomas desenvolvem-se ao redor do feto e progridem em direção ao limite distal da corioalantóide no corno vazio. Durante a gestação estes placentomas aumentam em diversas vezes seu diâmetro original. São inicialmente discóide, adquirindo posteriormente a forma de um cogumelo pediculado, medindo de 2 a $3 \mathrm{~cm}$ de comprimento, com maior desenvolvimento na parte central do corno gestante (LATSHAW, 1987). O placentoma de búfalas Carabao foi descrita por Enriquez-Yap (1974) como sendo uma estrutura em forma de cogumelo com uma superfície livre convexa e um pequeno pedúnculo. Leiser et al. (1997a) relatam que a placenta bovina apresenta o placentoma em forma de cogumelo e constituído de dois componentes: o tecido materno do pedúnculo caruncular sustentando os septos e lâminas basais do placentoma, o tecido fetal o qual forma cotilédones orientados para o lado fetal com as lâminas coriônicas do placentoma recobrindo o tecido materno como uma capa. Em ovelhas os placentomas são como taças, exibindo árvores vilosas com o álamo, cilíndricas e longas (LEISER et al., 1998).

A formação do placentoma inicia-se através do crescimento do trofoblasto que são depois preenchidos por mesênquima vascular. As vilosidades fetais começam a preencher as depressões carunculares denominadas de criptas uterinas, onde esse crescimento faz com que ocorra escavação do trofoblasto arranjado como arcos dos quais as vilosidades desenvolvemse por ramificação. $\mathrm{O}$ endométrio hipertrofia e cresce ao redor da vilosidade $\mathrm{O}$ resultado desse processo é a caracterizando o placentoma. E essa interdigitação produz uma firme aderência entre as porções fetal e materna do placentoma. Em bovinos os placentomas estão dispostos em 4 fileiras, acompanhando o arranjo nas carúnculas uterinas: 4 fileiras no corpo do útero, 3 no centro e 2 na extremidade dos cornos uterinos, o tamanho dos placentomas depende do estágio da gestação, ocorrendo um aumento deste tamanho com o decorrer da gestação, e o crescimento dos placentoma é muito grande durante a primeira metade da gestação, tanto em peso, altura como em diâmetro (BJORKMAN, 1954). 
Os placentomas apresentam um formato esférico, em forma de ferradura, de feijão ou de rim no inicio da gestação. Durante o meio da gestação eles tomam a forma de cogumelo, "S" ou elíptico e no final da gestação eles são elípticos em forma de conta e apresentaram uma forma totalmente irregular (SILVA, 2004). Miglino (1991) ao estudar a placenta de Bos taurus observa que há uma predominância de placentomas ovóides, os de formato irregular estavam em diversos graus de fusão, e classificou-os conforme o tamanho em pequenos, médios e grandes, e observa uma predominância de placentomas médios. Alguns placentomas apresentam-se formando cachos e foram considerados como médios. Ao estudar a placenta de búfalas da raça Carabao, Enriquez-Yap (1974) descreveu o placentoma com sendo uma estrutura em forma de cogumelo com uma superfície livre convexa e um pequeno pedúculo. Os placentomas diferem em sua estrutura macroscópica, tornando-se côncavo no lado fetal na ovelha e cabra, mais convexos na vaca e achatados em antílopes, as diferenças são provavelmente, sem significado funcional (BARRETO JUNIOR et al., 1995; LAMMING, 1994; WOODING et al.; 1997)

O número de placentomas na vaca varia de 70 a 142 com arranjo linear em 4 fileiras no centro, 3 na porção média e 2 nas extremidades dos cornos uterinos (HAFEZ, 1954). Esse mesmo autor em 1955 observa que o número de placentomas em búfalas varia de 42 a 147, contrastando com o encontrado nas vacas de 70 a 142. Nas búfalas os maiores placentomas chegaram a $13 \mathrm{~cm}$ e são observados próximos ao meio do saco corioalantóide em oposição ao dorso do feto. Abdel-Raouf e Badawi (1966) compararam as placentas de búfalas e de bovinos e citam que nos bufalinos o número de placentomas varia de 71 a 229 com uma média de 128, onde 68 no corno gestante e 55 no corno não gestante, este resultado contrasta com o relatado por Hafez (1955). Acharya e Kohli (1968) estudaram as membranas fetais de 234 vacas da raça Hariana e observaram que o número de placentoma variou de 27 a 136 com uma média de 72,23 $\pm 0,89$, sendo o número médio de placentomas no corno gestante de $43,89 \pm 2,93$ e no corno não gestante de 32,75 , quanto ao tamanho eles afirmam que o corno gestante apresentou um maior percentual de placentomas grandes $(49,07 \%)$ em relação ao corno não gestante $(28,14 \%), \pm 2,83$.

Kadu e Kaikini (1974) estudando a placenta de vacas indianas observaram que o número de placentomas variou de 27 a 136. Em 70 vacas da raça Shiwal, o número de 47 a 149 com média de 82,28, onde o número médio de placentomas no corno gestante foi de $51,71 \pm 1,30$ correspondendo a $62 \%$ e no corno não gestante de $30,57 \pm 1,04$ com percentual de 37,16\%. Em vaca Zebu, afirmam ter encontrado uma média de 69,0 placentomas, sendo uma média de 41,0 no corno gestante e de 28,1 no corno não gestante. Em Bos indicus com 
mais de 8 meses de gestação o número de placentomas apresentou média de $88 \%$ (SILVA, 2004).

A estrutura do placentoma de búfalas é composta por duas áreas, ou seja, uma área materna de sustentação e uma área fetal. O formato do placentoma bufalino varia de acordo com o período de prenhez, apresentando um contorno circular, reniforme, elíptico ou quadrangular, mas geralmente possui formato de cogumelo com um pedúnculo pequeno, na fase final apresentaram um aspecto esférico ou em forma de ferradura, feijão ou rim, na metade da gestação, os placentomas apresentavam principalmente a forma de cogumelo, "S" ou são elípticos e irregulares (KATHIRESAN et al., 1992; PEREIRA, 2000).

Stickland e Purton (1977) analisando o coeficiente de correlação entre a distância céfalococcígea permite estima-se o período de prenhez (Crow-Rump).Essa medida foi realizada considerando ambas as áreas, média e total, ocupadas pelos placentomas, concluindo que há uma forte correlação e informam ainda que esta correlação inexiste entre o Crow-Rumpo e o número de placentomas, sugerindo não haver variação do número de placentomas com idade fetal e demonstram que estes crescem em tamanho, porém não em quantidade, afirmam ainda que o baixo número de placentomas observados pode ser devido a uma deficiência nutricional. Ram e Chandra (1984) observaram ao estudar a placenta de búfalas, que com o avanço da prenhez, há aumento gradual do número de placentomas na vaca e búfula, onde este número de placentomas aumenta de 89 para 173 durante o início da gestação para então diminuir no final da gestação de 162 para 77, este decréscimo é observado principalmente quando o feto está em estágios de crescimento a um crown-rump de 37,0 a $45,0 \mathrm{~cm}$. Na prenhez avançada a medida cefalococígea, pela qual se estima o período de prenhez (CR) aumentou de 30 para $72 \mathrm{~cm}$, entretanto o número de placentomas diminuiu de 162 pra 77, esta diminuição era particularmente marcada durante o estágio de CR 37 para $45 \mathrm{~cm}$. O número de placentomas era geralmente maior no corno uterino gestante em relação ao corno não gestante (HAFEZ, 1982; KING et al., 1980; MARQUES JUNIOR et al., 1993).

Santos et al. (1996) estimaram a proporção volumétrica de dois diferentes componentes do placentoma de vacas leiteiras, principalmente no que diz respeito a proporções de células binucleadas. Esta proporção era muito superior nas vacas que apresentavam retenção placentária, já que o experimento contemplava vacas com e sem retenção placentária. Não houve diferença significativa em relação aos demais componentes estrutural, como tecido conjuntivo materno, epitélio das criptas carunculares, tecido conjuntivo fetal e epitélio trofoblástico, tendo somente sido relevante à proporção volumétrica das células binucleadas, indicando que estas células estão possivelmente envolvidas com o 
mecanismo que determinam à retenção placentária em vacas leiteiras. Malard et al. (1996) também estudaram a proporção volumétrica dos componentes estruturais da placenta de vacas zebu ao longo da gestação e observaram um aumento relativo do epitélio trofoblastico e diminuição dos componentes estruturais maternos ao longo da gestação, os quais relacionaram com as mudanças morfológicas importantes voltadas para a maturação do placentoma e que, possivelmente, influenciam o processo de liberação normal da placenta.

\subsubsection{Vilos Coriônicos}

Os vilos coriônicos consistem de um eixo principal que se ramifica progressivamente em vilos de ordens maiores, constituem ainda de mesênquima vascular recoberto por uma única camada de trofoblasto e, geralmente, adaptam-se a criptas uterinas correspondentes, onde o septo principal dá origem a septos de ordens secundárias e ordens maiores para formar o componente materno (BJORKMAN, 1987). As vilosidades ou penetram diretamente dentro do endométrio ou simplesmente se entremeiam com pregas vasculares da superfície endometrial.

$\mathrm{O}$ aspecto e a disposição dos vilos coriônicos determinam em grande parte o modelo de implantação do cório e endométrio, formando quatro diferentes tipos de placenta; difusa para os suínos, cotiledonária para os ruminantes, diferenciando esse tipo em: oligocotiledornária para os cervídeos e multicotiledonária para os bovinos, zonárias para carnívoros e discoide para primatas (BARONE, 1976).

A estrutura do tipo de vilos é agrupada dentro de uma série de unidades esféricas conhecidas como lóbulos ou placentomas (KAUFMANN; BURTON, 1994). Cada lóbulo surge de uma placa coriônica por um tronco viloso grosso derivado das trabéculas. O tronco principal se ramifica repetidamente e embora algumas subdivisões se estendam para longe da placa basal, os vilos ancorados, terminam em sua maioria livremente no espaço interviloso. Podem ser distinguidos cinco tipos de vilos baseados no calibre, característica do estroma e estrutura dos vasos, refletindo diferentes subdivisões da árvore vilosa.(SCHOENAU, 2000).

Hafez (1954) também classificou as placentas dos mamíferos levando-se em consideração a distribuição e formação dos vilos coriônicos, descrevendo-as da seguinte forma: Placenta difusa, onde os vilos coriônicos estavam distribuídos uniformemente sobre toda a superfície do cório; placenta cotiledonar ou múltipla na qual os vilos são restritos a 
certas áreas, os cotilédones; placenta zonária e placenta discoidal, nas quais as relações materno-fetal se fazem em uma faixa ou disco, respectivamente.

Winsatt (1950) descreve que na vaca as vilosidades coriônicas ramificadas são fortalecidas dentro de numerosas estruturas arredondadas como tufos, os cotilédones os quais estão separados por extensas áreas de cório liso (sem vilosidade) denominada de placenta intercotiledonária ou córion membranoso. A formação das vilosidades nesta espécie inicia perto do final do primeiro mês de gestação e muitas vilosidades com ramificação secundárias estão presentes com 35 dias, assim havendo um significado grau de adesão entre as porções fetais e maternas da placenta nesse período.

Na superfície do saco coriônico há produção de processos em forma de dedos ou vilos, formados por uma única camada de trofoblasto. O epitélio endodérmico do alantoide não se continua para dentro do vilo, estes vilos se adaptam dentro de depressões na parede do útero, conhecido como criptas. Os vilos não se aderem próximo às paredes das criptas, e ao nascimento são facilmente removidos sem danificar o tecido materno. Na placenta cotiledonária, os vilos estão reunidos em cotilédones e regiões interferidas de córion liso (JENKINSON, 1925). Björkman e Sollen (1960) observaram o placentoma bovino e concluíram que os vilos coriônicos ramificados adaptam-se em criptas das carúnculas uterinas, onde essas criptas carunculares estão acompanhadas por um epitélio cuboidal simples de origem materna, já os vilos consistem de mesênquima vascularizado provido por uma simples camada de ectoderma trofoblástica celular. Na base do vilo coriônico principal, o trofoblasto parece ser pseudoestratificado, especialmente onde ele conecta com o septo materno (SHARMA et al., 1983).

O estudo da morfologia do vilo, também é importante para avaliar a formação placentária em vários aspectos. Mayhew e Sisley (1998) realizaram um estudo quantitativo dos vilos, trofoblastos e poros intervilosos em placentas de mulheres com diabetes militus, fazendo um comparativo dessa estrutura em mulheres normais.

Davies e Winsatt (1966) descreveram que os vilos coriônicos da placenta da ovelha consistem de uma região central de mesênquima corioalantóide vascular e uma camada externa de trofoblasto colunar. Os componentes celulares da cobertura coriônica dos vilos são células trofoblásticas colunares e células gigantes binucleadas. Uma importante característica dos vilos coriônicos do placentoma estágios avançados de prenhez, é a invasão do trofoblasto colunar pelos capilares corioalantóide. Neste processo, o qual não foi observado em nenhum estágio na zona intercotiledonaria, os capilares começam a invaginar-se profundamente dentro do epitélio coriônico cujas células estão intimamente moldadas a eles. Dantzer (1999) ao 
estudar a placenta de bovinos cita que durante a gestação os vilos do septo criptal começam alongar-se, aprofundar-se e ramificar-se, isto leva a uma sucessiva diminuição no mesênquima nos vilos e no tecido conjuntivo do septo criptal.

Pelagalli et al. (1973) descreveram que a rede vascular das placentas de ovelhas, vacas e búfalas são diferenciadas ao nível dos cotilédones, e a vascularização dos vilos coriônicos é representada, em geral, por um calibre uniforme e fino dos vasos menores, este aspecto diferencia-se nas três espécies, pelo fato tamanho diferente dos vilos, que são maiores nos búfalos e menores nos bovinos e ovinos. Dantzer et al. (1988) ao descreverem a placenta de caprinos e ovinos comentaram que a artéria fetal entra no placentoma pela depressão central do lado fetal e ramifica-se em artérias menores, as quais estão localizadas no centro dos vilos fetais, e seguem em direção ao topo dos vilos. Ela envia arteríolas menores para dentro do lado ramificado do vilo, onde próximo às terminações ramificadas dos vilos, a arteríola continua-se na rede capilar. $\mathrm{Na}$ base dos vilos, a rede capilar continua-se com as vênulas fetais.

Mayhew et al. (2003a) verificaram usando também análises estereológicas, que a forma como os vilos se apresentam quanto a sua área total de superfície e volume demonstram-se alterados em casos de gestações complicadas. Mayhew e Barker (2001) chegaram à conclusão que as disposições de tipos de fibrinas no vilo trofoblástico durante a gestação, tinha maior impacto em casos de pré-eclampse.

A vascularização feto-placentária quando consideramos os vilos, ela ocorre em duas fases principais, sendo distinguidas por cronometragem, padronagem (configuração) e relação molecular. Estas trocas na condução da vascularização ajudam para determinar a maturidade e eficiência dos vilos, onde se verifica que a transição da média-gestação envolve uma troca na produção do ramo principal da árvore vilosa (vilos intermediários imaturos, se maturando em tronco do vilo), no ramo fino periférico (vilo maturo intermediário e vilo terminal) estão longe da maior eficiência no processo de troca (CASTELLUCCI et al., 2000). A descrição e interpretação apropriada das trocas na vascularização dos vilos são fundamentais quando consideradas as formas apropriadas de intervenção e terapia (MAYHEW, 2003). 


\subsubsection{Hematoma Placentário}

A presença de hematomas já foi citada em várias espécies de animais e ele considerando como fonte de obtenção de ferro pelo feto. Existe vários sinônimos para a palavra hematoma, isso porque essa estrutura é tica como subunidade placentária, zona hemófaga ou órgão hemófago, e sua localização é descrita na zona paraplacentária, resultante do extravasamento de sangue materno, o que parece ser mais distinto no final da gestação (DANTZER, 1999).

Em áreas onde ocorrem hematomas, sangue materno se acumula em grandes quantidades opostas ao trofoblasto. Várias intervestigações tem mostrado que os processos de erigofagocitose em mamíferos têm características comuns sob varais condições e envolvem alterações sub-celulares típicas da membrana dos eritrócitos e hemoglobina sob ataque das enzimas lisossomais (PEREIRA, 2003).

Em carnívoros domésticos, Amoroso (1952) verificou que há presença de dois hematomas marginais os quais nos caninos são grandes e volumosos, fáceis de serem identificados a olho nu, dispostos regulamente ao longo das margens das zonas paraplacentárias. Ambrósio (2003) que em cães com 20 dias de gestação não havia diferença entre cinta placentária e hematoma na superfície luminal do saco gestacional. No gato doméstico o hematoma é visto em áreas marrons na margem de cada lado da placenta ou visto como uma grande área hematomal da face antimesometrial da placenta (DANTZER, 1999); Leiser e Enders (1980a) descreveram hematomas na zona extravasada na placenta do gato doméstico, onde inclui áreas juncionais paraplacentárias e hematomas marginais, onde o epitélio uterino torna-se altamente proliferativo, especialmente nas pregas ou protusões.

Nos ruminantes, durante a segunda metade da prenhez, extravasamento de sangue materno pode ser visto em ares na base dos vilos e na ovelha, na área interdigitada do placentoma.

Em vacas o extravasamento sanguíneo surge a partir do $76^{\circ}$ dia de prenhes e pode ser visto em áreas nas bases dos vilos. Este acúmulo é resultante da destruição do tecido uterino no topo dos septos maternos, sendo apenas encontrado ocasionalmente em vacas. O sangue extravasado segue em direção ao espaço entre as camadas placentárias maternas e fetais, logo, o extravasamento é dentro da cavidade uterina.

Uma das características morfológicas mais impressionantes no placentoma da placenta de ovelha é a presença de hematomas na base dos vilos coriônicos, sendo esta região chamada 
de zona arcada. Estes hematomas aparecem em 70-80 dias de prenhez e são desenvolvidos em estágios avançados da prenhez, supões que estes hematomas sejam resultados da erosão direta dos capilares feitas nos topos dos septos intervilosos pela junção trofoblástica, mas algumas observações histológicas sugerem que o escape de sangue é somente esporádico e pode ser induzido, por outro lado, pela erosão direta dos vasos maternos. Em áreas onde ocorrem hematomas, sangue materno se acumula em grandes quantidades opostas ao trofoblasto e eritrócitos são ingeridos pelas células trofoblásticas. Várias investigações têm mostrado que os processos de eritrofagocitosose em mamíferos têm características comuns sob várias condições e envolvem alterações sub-celulares típicas da membrana dos eritrócitos e hemoglobina sob ataque das enzimas lisossomais (MYGKAYA et al., 1976). De acordo com Murai e Yamauchi (1986) o sangue extravasado, apareceu no espaço entre a base do vilos coriônicos e septos carunculares no $76^{\circ}$ dia de prenhez da ovelha, esta estrutura aumentou em número e tamanho com o progresso da prenhez, e houve desenvolvimento do hematoma após 150 dias de prenhez. Em ovelhas esse extravasamento e acúmulo de sangue materno podem ser visto na área interdigitada do placentoma (LATSHAW, 1987).

Topograficamente, na placenta dos bovinos, as criptas nas carúnculas nas quais os vilos se estendem, são revestidos por um epitélio cúbico simples de origem materna, estes epitélios pode ser eventualmente, incompleto ou estar ausente no septo materno da carúncula e, nesse caso, o tecido materno do útero é exposto e algum sangue materno pode extravasar no final da gestação, mas nunca de modo regular e abundante como ocorrem nas ovelhas Winsatt (1980).

Leiser e Enders (1980a) descrevem hematomas na região central da placenta zonária a termo do gato doméstico, que inclui áreas juncionais paraplacentárias e hematomas marginais, o epitélio uterino se torna altamente proliferativo, especialmente nas pregas e protusões.

\subsection{PLACENTAÇÃO EM BOVINOS CLONADOS}

Poucos estudos foram realizados em placentas de bovinos clonados, mas as anormalidades placentárias estão associadas à alta mortalidade nos programas de clonagem em mamíferos (HILL et al, 2001). Na placenta de clone estes mesmos autores verificaram que não houve alteração no peso da placenta, afirmaram que ela é recuperada intacta 3 horas após o parto e o peso está dentro do limite normal $(4,3 \mathrm{~kg})$. 
Ao estudar placentas de novilhos clonados da raça "holstein" (HILL et al., 2001), verificou que o corioalantóide nesses animais apresenta somente 26 cotilédones, onde apenas doze destes cotilédones desenvolvidos são funcionais, seis desenvolveram doenças e oito foram degenerados. Os doze cotilédones funcionais alcançaram o diâmetro de 8 a $20 \mathrm{~cm}$. A pesar da redução no número de placentomas, não havia existência de placentação. A deficiência morfológica da placenta verificada permite analisar que mesmo nessas condições o animal está apto a suportar o desenvolvimento do feto, resultando em um novilho viável.

Hill et al, (2000) estudaram placentas de fetos de bovinos clonados no primeiro trimestre de gestação e constataram que a anormalidade placentária é a maior causa de mortalidade nesse período de gestação. Para o seu estudo esses autores coletaram seis placentas de vacas com fetos clonados e quatro controles; foram comparados entre os dias 35 60 de gestação. Duas placentas de clones mostraram desenvolvimento rudimentar, sendo indicados pela superfície do epitélio cuboidal trofoblástico e vascularização reduzida, considerando que duas outras possuíam um número reduzido que revelaram discernir áreas cotiledonárias. Duas placentas clonadas remanescentes foram similares ao controle, apesar de uma conter cotilédones hemorrágicos. Eles chegaram à conclusão que a fraca viabilidade de fetos clonados durante os dias 35-60 está associada com cada desenvolvimento rudimentar ou marginal do corioalantóide.

Verechia et al., (2003), estudaram a arquitetura e microvascularização da placenta de bovinos clonados, comparando com animais não clonados. Esses autores estudaram 39 placentomas de bovinos clonados e verificaram áreas hemorrágicas na membrana córioalantóide, o diâmetro do placentoma foi de $21 \mathrm{~cm}$ com espessura de $1 \mathrm{~cm}$ e pesando $150 \mathrm{~g}$. Verificaram também que no lado fetal o tronco de poucas árvores vilosas é formado por uma única artéria e duas veias, e que eles possuem um vilo de origem inserido dentro de criptas vasculares na superfície materna. As artérias de origem diferiram daquelas encontradas na gestação de animas não clonados e o sistema capilar materno aparece menos ramificado com

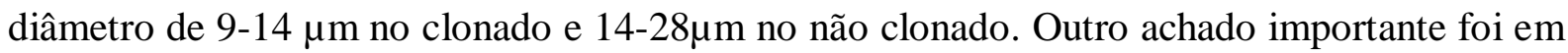
relação aos vilos, onde estes parecem ser curtos quando deixam o eixo materno e a árvore vilosa apresenta arranjo desorganizado, sugerindo uma falta de arquitetura para suportar o crescimento fetal, além de que algumas células trofoblásticas mostrarem núcleos alterados.

Considerando os achados, Verechia et al., (2003) chegaram à conclusão que os placentomas de bovinos clonados exibem alterações no padrão vascular e arranjo dos vilos fetais com as criptas maternas, além de apresentarem um número total de placentomas inferior 
ao de gestações de animais não clonados, 39 e 84 respectivamente. Esses resultados são semelhantes ao encontrado por Hill et al., (2001) citado anteriormente.

Pesquisas futuras devem focalizar-se em fatores que promovem crescimento placentário vascular e interação materno-fetal que promove fixação placentária e formação de vilo , sugestão de Hill et al, 2000 ao finalizar o seu estudo.

\subsection{ASPECTOS QUANTITATIVOS DA PLACENTA}

O estudo estereológico da placenta de bovinos é necessário para determinar o padrão desta estrutura no seu aspecto quantitativo por meio de parâmetros estereológicos, uma vez que para esta espécie encontramos apenas estudos quantitativos que utilizaram métodos morfométricos em suas análises (BERTOLINI et al., 2002; LAVEN; PETERS, 2001; LEISER et al. 1997b; MILES, 2004). Mas podemos encontrar relatos da utilização de métodos estereológicos para análise da placenta em outras espécies (DRAGAN et al., 1997) camundongos (COAN et al., 2004), em eqüinos (ALLEN et al., 2002) e muares (WILSHER; ALLEN; 2003).

A estereologia é um dos métodos quantitativos utilizada na quantificação morfológica tridimensional. Em 1985 surgiu a chamada "Nova Estereologia" que introduzido novos conceitos e metodologias. Os métodos da nova estereologia permitem interpretação funcional e morfológica de células e órgãos (MAYHEW, 1991).

Embora este estudo em animais ainda seja restrito, em humanos podemos encontrar inúmeras referencias sobre a utilização dos métodos estereológicos nas mensurações das estruturas placentárias (ALI, 1997; BURTON et al., 1996; BUSH, 2000; LEE e MAYHEW, 1995; MAYHEW; BURTON, 1997; MAYHEW e SISLEY, 1998; MAYHEW et al., 2003a; MAYHEW et al. 2003b; ONG et al., 2004; SIMPSON et al., 1992;). 


\section{Materiais e Métodos}




\section{MATERIAL E MÉTODOS}

O material utilizado e os métodos empregados neste trabalho estão descritos em tópicos específicos.

\subsection{MATERIAL}

Foram coletadas 4 placentas de bovinos (Bos indicus) clonados da raça Nelore, assim como 4 placentas de bovinos (Bos indicus ) não clonados da mesma raça, entre 240 e 290 dias de gestação. Utilizando-se de sistema teste (área $=0,6 \mathrm{~cm}^{2}$ ) sobreposto à placenta uma fração de $1 / 8\left(\mathrm{fn}^{-1}=8\right)$ dos placentomas foram coletados de maneira uniforme, aleatória e sistemática. Desta forma, foram coletados 1 a 3 placentomas por placenta, onde nas placentas de clonados foram coletados respectivamente, 2, 2, 3 e 1 placentomas, já nos não clonados foram coletados 2 placentomas de cada placenta.

As placentas dos bovinos clonados e as placentas de bovinos não clonados foram provenientes do Departamento de Reprodução Animal da Faculdade de Medicina Veterinária e Zootecnia da Universidade de São Paulo, campus Pirassununga e do Hospital Veterinário da Universidade de São Paulo- FMVZ.

Após o nascimento os fetos foram pesados e as placentas foram separadas do útero por incisão na base do placentoma, posteriormente pesada sem desconectar os cotilédones das carúnculas. À seguir o número de placentomas por placenta foi obtido nos dois tratamentos. Consideramos na contagem os maiores de $1 \mathrm{~cm}$.

\subsection{MÉTODOS}

Nesta seção estão descritos todos os métodos utilizados para a obtenção dos resultados. 


\subsubsection{Microscopia de Luz de Cortes Semi-finos}

As amostras (placentomas) foram fixadas em solução Karnousky modificada [glutaraldeído $(2,5 \%)+$ formoldeído $(2 \%)$ em tampão de cacodilato de $\mathrm{Na}(\mathrm{pH} 7.4),(0,125$ M)]. Depois de fixados foram lavados em tampão cacodilato $(0,125 \mathrm{M})(\mathrm{pH} 7.4)$ e pós-fixados em tetróxido de ósmio 2\% (Osmium tetroxide 4\% w/w solution in water, polysciences, Inc., USA) por 1 hora. Seguiram novas lavagens em tampão cacodilato, contrastação em bloco com solução acetato de uranila saturada e posteriormente foram desidratados em concentrações crescentes de etanol (de 50\% a 100\%) terminando em óxido de propileno. Durante 12-16 horas, as amostras foram mantidas sob agitação em uma mistura 1:1 de óxido de propileno (Propylene oxide EM Grade, Polyciences, Inc., USA) e resina Araldite polyscience® . Em seguida, esta mistura foi substituída por resina pura, onde os materiais permaneceram por mais 4 a 5 horas.

Após esse tempo as amostras foram colocadas em moldes com resina pura e orientadas de modo de que a face de corte do bloco contivesse sempre a interface materno-fetal para a observação. Posteriormente os materiais foram mantidos em estufa a $60^{\circ} \mathrm{C}$ por 72 horas permitindo a polimerização da resina. Os blocos contendo as amostras foram cortados com o auxílio do ultramicrótomo Leica Ultracut UCT em cortes semi-finos de 1- $2 \mu \mathrm{m}$ de espessura. Posteriormente, foram corados com solução alcoólica de azul de toluidina.

\subsubsection{Estudo Estereológico}

Para realizar o estudo estereológico é necessário à utilização de amostras sistematicamente e uniformemente aleatórias e todos os campos de amostragem devem ter a mesma probabilidade de serem selecionados, desde o momento da coleta até o processamento final dos dados (Figura $1 \mathrm{~A}-\mathrm{F})$.

Os placentomas selecionados foram seccionados seriadamente, paralelos entre si e transversais ao eixo vertical com distâncias conhecidas (Figura1 B). As fatias obtidas em cada placentoma passaram por um novo processo de seleção sistemática e aleatória utilizando-se 
um iniciador aleatório entre $1-\mathrm{f}_{\mathrm{n}}$. Então as fatias selecionadas passaram pelo processo de isotropização utilizando o método do orientator (MATTFELDT et al., 1990) (Figura 1 C).
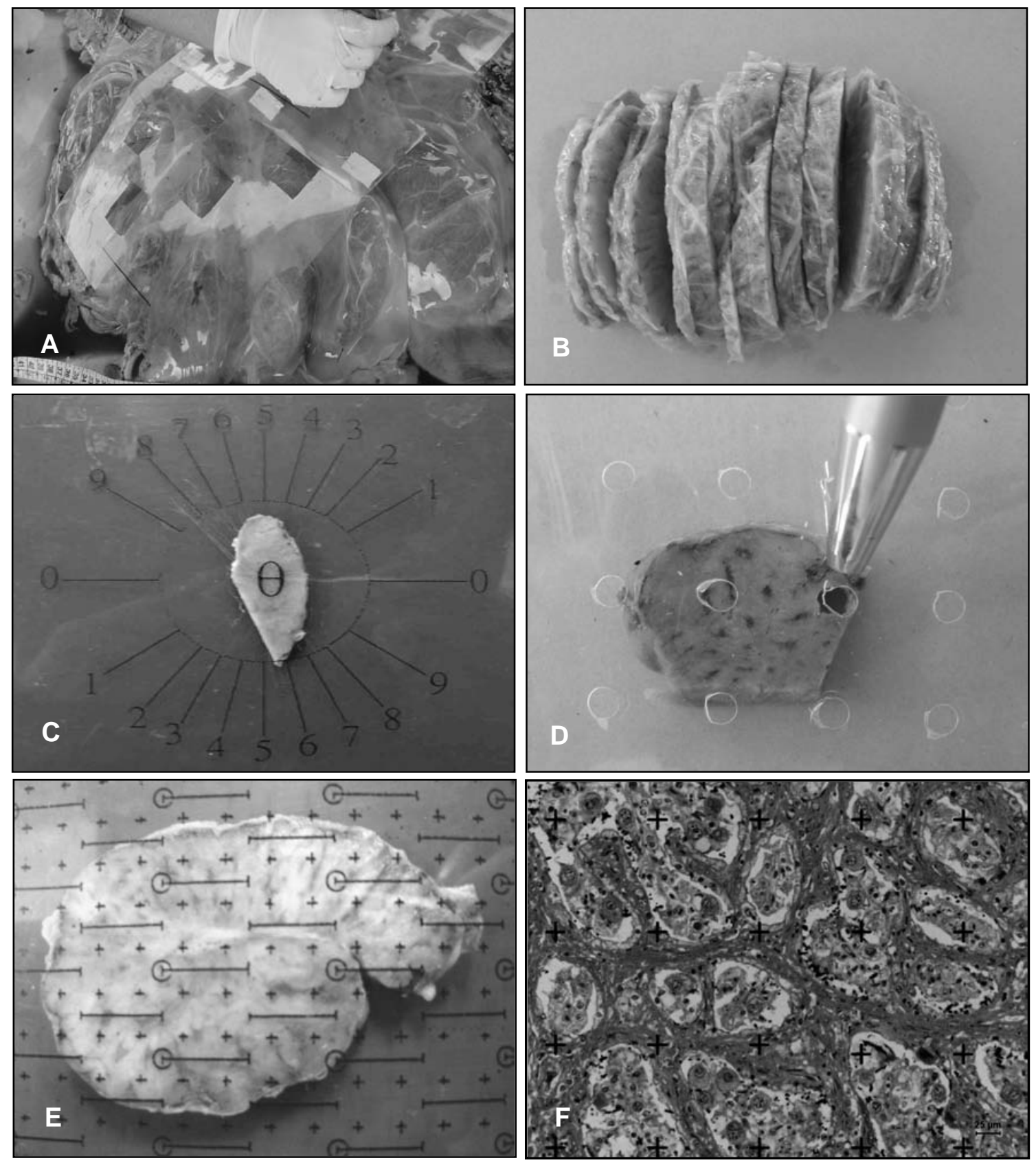

Figura 1 (A- F) - sistemas testes utilizados nos métodos estereológicos. A - Sistema teste posicionado sobre a placenta no momento da coleta para selecionar os placentomas de forma sistematicamente aleatória. B - Placentoma cortado transversalmente e sequencialmente para processamento do material e estimativa de volume pelo Princípio de Cavalieri. C - Fragmentos de placentoma com o sistema teste (método do orientator) utilizado para isotropisar amostras. D - Sistema teste de pontos e interceptos que também é utilizado para estimar o volume referência no Princípio de Cavalieri. E - Sistema teste utilizado para selecionar o campo a ser coletado. F - Fotomicrografia de uma área selecionada contendo vilos cor ônicos (V) da placenta de animal clonado mostrando o sistema teste de pontos (cruzes), sobreposto à imagem na tela de um computador. Coloração: Azul de Toluidina, Escala de Barra: $25 \mu \mathrm{m}$. 
Com os cortes já isotrópicos e uniformemente aleatórios, foi possível selecionar fragmentos (cubos) de aproximadamente $0.5 \mathrm{~cm}^{2}$ para o processamento do material. Para isso utilizamos um outro sistema-teste sobre a amostra isotrópica e selecionamos o fragmento a ser processado com ajuda de um trocarter com diâmetro de 4 mm (Figura $1 \mathrm{D}$ ).

Do total dos cubos de uma fração $\left(1 / f_{n}\right)$, foi novamente escolhida de forma sistematicamente aleatória (usando um iniciador aleatório entre 1 - 2) e embebida em resina araldite (vide microscopia de luz de cortes semi-finos).

\subsubsection{Amostragem dos Campos Histológicos}

A amostragem dos campos histológicos analisados foi feita por meio da interposição de um sistema teste composto por oito áreas-teste (At) delimitadas por linhas de inclusão e exclusão "acceptance and forbidden lines" (cada área teste foi de $0.3025 \mathrm{~cm}^{2}$ ). Para análise, foram consideradas as estruturas vilosas que estavam dentro da At e que não tocaram as linhas de exclusão. De fato, uma fração $1 / f_{n}$ de (At) (usando um início aleatório entre 1- 2) foi efetivamente considerada para o estudo estereológico. Portanto, assim como na coleta do material, a amostragem histológica foi sistematicamente aleatória seguindo o padrão SURS "Systematic uniformly random sampling", oferecendo a mesma oportunidade para todo o material ser selecionado (MAYHEW et al., 2003a) proporcionando assim uma maior precisão em relação à amostragem aleatória simples (GUNDERSEN; JENSEN, 1987).

As imagens dos campos histológicos foram capturadas e analisadas utilizando o programa de análise de imagem Leica Q-Win ${ }^{\odot}$ devidamente calibrado e equipado com câmera digital DFC 300FX Leica ${ }^{\circledR}$.

3.2.2.2 Volume Referência do Placentoma (Princípio de Cavalieri, 1635)

Segundo o Princípio de Cavalieri o volume pode ser estimado globalmente através de uma serie de planos paralelos separados por uma distância conhecida. A estimativa se dá pela distância entre as secções ou fatias ( $\mathrm{d}$ ou k, sendo d a nomenclatura utilizada para cortes 
macroscópicos e k para cortes microscópicos) multiplicada pela somatória das áreas ( $\Sigma \mathrm{a}) \mathrm{de}$ cada secção: Vref $=$ d $($ ou k) $\times$ $\Sigma$ a.

O volume referência (Vref) dos placentomas foi obtido através da análise macroscópica. Cada placentoma foi seccionado transversalmente ao longo do seu eixo vertical. O total do número das fatias obtidas foi divido pelo eixo longo do placentoma, obtendo assim a distância média (d) que é igual a espessura média de cada fatia. Posteriormente foi colocado sobre cada fatia um sistema teste para calcular a área de cada secção do placentoma que correspondia à somatória do número total de pontos que tocavam a superfície da amostra, multiplicado pela área de cada ponto (Figura 1 E). Obtendo-se a distância entre as fatias e área de cada secção do placentoma, estimamos o volume global da estrutura. A fórmula utilizada foi: Vref $=\mathrm{d}$ x $\Sigma$ a.

\subsubsection{Densidade de Volume "Volume Density" (Vv)}

É expressa utilizando um sistema lattice de pontos sobrepostos a imagem dos vilos projetada na tela de computador (figura 1 F). Foi estimado pela razão do número de pontos que atinge o os vilos (Pv) pelo número de pontos que atingiram o espaço referência (Per). $\mathrm{Vv}=\mathrm{Pv} /$ Per. Este parâmetro permitiu-nos estimar a fração de volume que os vilos ocupam no volume total da placenta.

\subsubsection{Volume Star (- Vstar)}

O volume star fornece uma estimativa direta local, e imparcial do volume que tem uma definição matemática estrita, ou seja, é o volume de um espaço 3D visível a partir de todos os pontos dentro deste compartimento.

A estimativa do volume star é obtida por meio de medidas de comprimento a partir de "point - sampled interceps" (GUNDERSEN; JESEN, 1987). A estimativa final foi calculada

por meio do comprimento do cubo intercepto: $\mathrm{V}_{(\mathrm{star})}=(\pi / 3) \times\left(-1 \mathrm{o}^{3}\right)$, onde $\left(-10^{3}\right)=$ média cúbica dos comprimentos dos "intercepts". 


\subsubsection{Densidade de Superfície (Sv)}

A densidade de superfície dos vilos foi estimada utilizando um sistema teste de pontos, colocado sobre as imagens dos vilos projetadas na tela do computador. Calculamos o número total de pontos que tocam os vilos $(\Sigma \mathrm{Pv})$ e o número total de interseções $(\Sigma \mathrm{I})$ que cruzam os mesmos e inserimos os valores na fórmula abaixo, onde $\ell$ corresponde ao aumento da imagem projetada (MAYHEW, 1991).

$$
\mathrm{S}_{\mathrm{V}}=2 \times \Sigma \mathrm{I} / \ell \times \Sigma \mathrm{PV}
$$

\subsubsection{6 Área de Superfície (Sa)}

A superfície de área é estimada multiplicando-se o valor encontrado na densidade de superfície (Sv) pelo valor do volume da referência (Vref.) (MAYHEW, 1990).

$\mathrm{Sa}=\mathrm{Sv} \times \mathrm{V}$ ref.

\subsubsection{Número de Unidades Volume Star $\left(\mathrm{N}^{-}\right.$Vstar $)$}

É calculado levando-se em consideração o volume total que os vilos ocupam na placenta e o tamanho dos mesmos. Permite estimar o número total de vilos que ocupam a placenta (MAYHEW; WADROP, 1994):

$\mathrm{N}^{-}$Vstar $=$Volume total de vilos $/^{-}$Vstar

\subsubsection{Eficiência da Placenta}

Para estimarmos a eficiência placentária utilizamos duas fórmulas: EP1 $=\mathrm{PP} / \mathrm{PF}(\mathrm{EP}=$ Eficiência da placenta; $\mathrm{PP}=$ Peso da placenta; $\mathrm{PF}=$ Peso do Feto), essa fórmula foi baseada em comunicação pessoal de Terry Mayhew $(2006)^{1}$, diferente do que foi citado na literatura por 
Dawy et al. (2005); Mesa et al. (2005); Miles et. al. (2004); Miles et. al. (2005) e Vonnahme et al. (2002), que calcularam a eficiência placentária pela relação do Peso do feto com o peso da placenta $(\mathrm{EP}=\mathrm{PF} / \mathrm{PP})$. A outra fórmula que utilizamos para calcular eficiência placentária foi $\mathrm{EP} 2=\mathrm{Sa} / \mathrm{PF}(\mathrm{Sa}=$ Superfície de área da placenta; $\mathrm{PF}=\mathrm{Peso}$ do feto $)$ comunicação pessoal de Terry Mayhew (2006) ${ }^{1}$.

\subsubsection{Análise Estatística}

Foram realizadas análises descritivas para todas as variáveis estereológicas avaliadas nas placentas, visando estabelecer o padrão característico verificados nos grupos comparativos, utilizando o programa Statistical analysis System (SAS, 2005). A análise de significância foi testada usando o procedimento PROC ANOVA (Test F). No caso de resultados significativos o Test F (Student) foi calculado.

Ainda foi realizada a análise da correlação momento-produto de Pearson, visando à busca de possíveis relações lineares entre os parâmetros estereológicos investigados. Nos casos em que as estimativas de correlações apresentavam-se altas $\left(r^{2}\right.$ X,Y $\left.>0.7\right)$, foram realizadas análises de regressão, visando estabelecer as funções que associam as variáveis estereológicas de maior importância biológica com as demais estimativas.

Adotamos a função linear $(Y=a+b X)$ para representar a analise de regressão, onde "a" o intercepto da linha de regressão com o eixo x; "b" a curvatura da linha de regressão; X variável independente ( no nosso caso foi o volume da placenta) e Y variável dependente: NP, EP2, Vv; Sa e N ${ }^{-}$Vstar. 


\section{Resultados}




\section{RESULTADOS}

Para facilitar a compreensão dos resultados, agruparemos os assuntos por tópicos, a saber: aspectos macromorfométricos; aspectos histológicos, estudo estereológico, eficiência placentária.

\subsection{ASPECTOS MACROMORFOMÉTRICOS}

O número total de placentomas na placenta de bovinos clonados variou entre 31 e 96 placentomas (média=62; $\mathrm{CV}=0,44$ ). Em bovinos não clonados os números mínimo e máximo de placentomas foram respectivamente 54 e 147 (média= 88 e CV=0,41).

O peso de cada placentoma foi estimado, sendo a variação encontrada nos placentomas dos animais clonados de 49,9g a 261,7g, (média= 124,1 g; CV=0,64). Em animais não clonados, estes valores foram de 69,5g a 162,1g (média=123,17g; CV=0.28). Em bovinos clonados o peso dos fetos variou de $34 \mathrm{~kg}$ a $51 \mathrm{~kg}$, (média= 39,7kg; CV=0,19). Em bovinos não clonados os fetos pesaram entre $32 \mathrm{~kg}$ a $40 \mathrm{~kg}$, (média=35.7kg; $\mathrm{CV}=0,09$ ).

Em relação às medidas macromorfométricas dos placentomas em bovinos clonados o comprimento variou entre $6,7 \mathrm{~cm}$ a $13,1 \mathrm{~cm}($ média $=10,9 \mathrm{~cm} ; \mathrm{CV}=0.20)$; já para a largura a variação foi entre $5,1 \mathrm{~cm}$ a $8,7 \mathrm{~cm}$ (média $=6,6 \mathrm{~cm} ; \mathrm{CV}=0,18$ ) e na espessura os valores mínimo e máximo foram respectivamente, $2,2 \mathrm{~cm}$ e $5,0 \mathrm{~cm}$ (média=3,5 cm e CV=0,30). Em placentomas de bovinos não clonados estes valores variaram de $6,9 \mathrm{~cm}$ a $11,7 \mathrm{~cm}$ (média= $10.23 \mathrm{~cm} ; \mathrm{CV}=0.17$ ) para comprimento, de 4,2cm a 7,2cm (média $=5,96 \mathrm{~cm}$ e $\mathrm{CV}=0.15$ ) para largura e de $2,4 \mathrm{~cm}$ a $4,0 \mathrm{~cm}$ (média $=3,09 \mathrm{~cm}$ e $\mathrm{CV}=0,20$ ) para espessura. As medidas encontradas para os placentomas em cada placenta, encontram-se descritas na tabelas 1 e 2 . 
Tabela 1 - Dados macromorfométricos dos placentomas de bovinos clonados: comprimento, largura, espessura e peso. São Paulo, 2006

\begin{tabular}{l|c|c|c|c|}
\hline \multirow{2}{*}{ Animal } & Comprimento & Largura & Espessura & Peso \\
\cline { 2 - 5 } & $\mathbf{( c m )}$ & $(\mathbf{c m})$ & $(\mathbf{c m})$ & $(\mathbf{g})$ \\
\hline Clonado 1 & 12,0 & 5,7 & 4,9 & 201,9 \\
\hline Clonado 2 & 8,7 & 5,9 & 3,3 & 116,0 \\
\hline Clonado 3 & 12,0 & 7,7 & 3,1 & 94,2 \\
\hline Clonado 4 & 9,5 & 6,2 & 2,2 & 74,0 \\
\hline Média & $\mathbf{1 0 , 6}$ & $\mathbf{6 , 4}$ & $\mathbf{3 , 4}$ & $\mathbf{1 2 1 , 5}$
\end{tabular}

Tabela 2 - Dados macromorfométricos dos placentomas de bovinos não clonados: comprimento, largura, espessura e peso. São Paulo, 2006

\begin{tabular}{|l|c|c|c|c|}
\hline \multicolumn{1}{c|}{ Animal } & Comprimento & Largura & Espessura & Peso \\
\cline { 2 - 5 } & $\mathbf{( c m )}$ & $\mathbf{( c m )}$ & $\mathbf{( c m )}$ & $\mathbf{( g )}$ \\
\hline Não clonado 1 & 7,8 & 6,1 & 2,5 & 83,6 \\
\hline Não clonado 2 & 10,8 & 6,1 & 3,8 & 161,5 \\
\hline Não clonado 3 & 11,3 & 6,7 & 2,7 & 129,5 \\
\hline Não clonado 4 & 11,7 & 4,20 & 3,3 & 112,8 \\
\hline Média & $\mathbf{1 0 , 4 1}$ & $\mathbf{5 , 7 4}$ & $\mathbf{3 , 1 1}$ & $\mathbf{1 2 1 , 8 8}$
\end{tabular}

\subsection{ASPECTOS HISTOLÓGICOS}

Do ponto de vista microestrutural, os placentomas de bovinos clonados e não clonados, não apresentaram diferenças entre si quanto aos seus elementos: epitélio uterino, estroma endometrial, trofoblasto e células mesênquimais. No entanto, observamos uma desorganização da árvore vilosa que foi mais evidente em relação aos não clonados, assim como um desarranjo do epitélio uterino que forma as criptas (Figuras 2A e 2B). Áreas hemorrágicas (hematomas) foram visíveis nos bovinos clonados (Figura 3). 


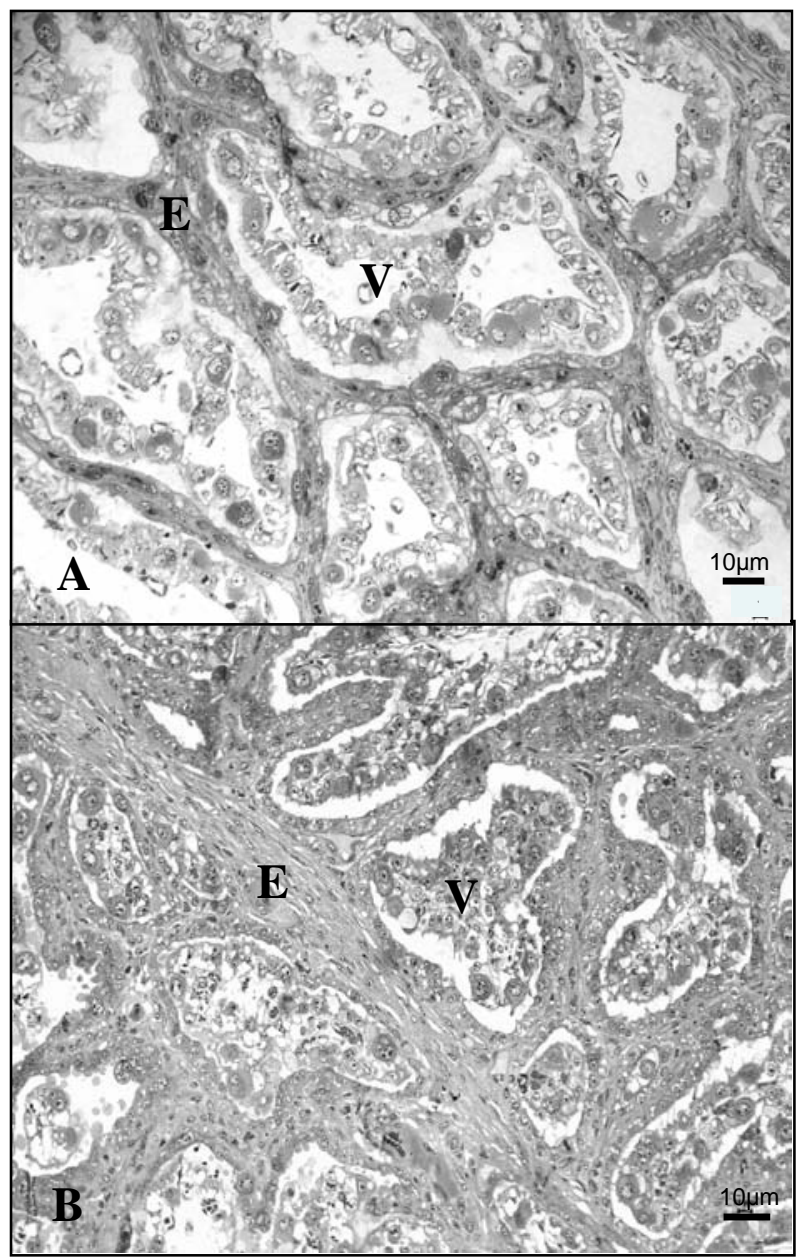

Figura 2 (A -B) - A- Aspecto microscópico do placentoma de um bovino clonado. Nota-se: endométrio (E). vilo coriônico (V) Técnica de

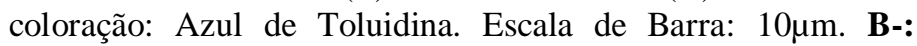
Fotomicrografia evidenciando a organização dos vilos coriônicos no placentoma de um bovino não clonado. Observase: endométrio (E). vilo coriônico (V) Técnica de coloração:

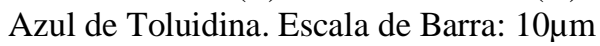

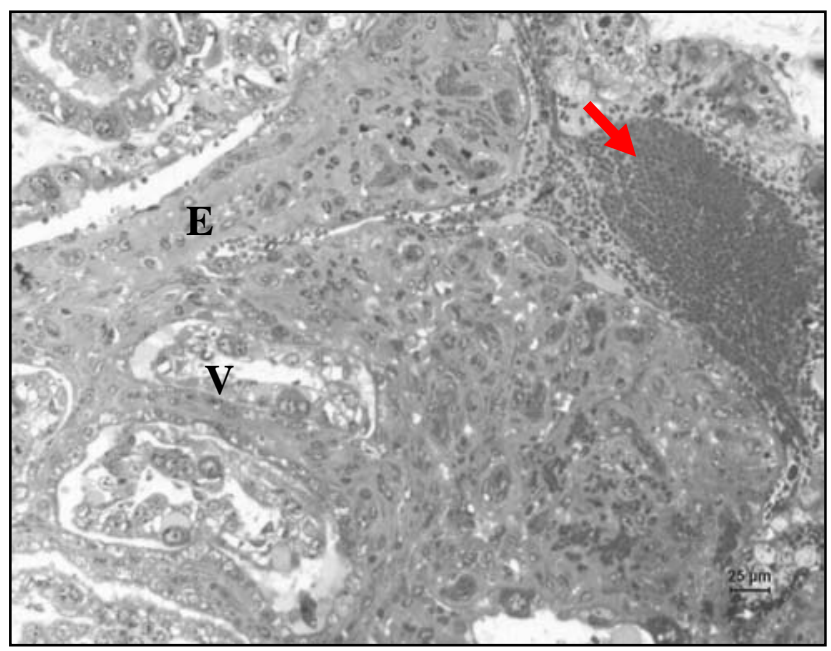

Figura 3 - Fotomicrografia do placentoma de um bovino clonado onde se observa uma área hemorrágica (hematoma) (seta). Observa-se ainda o endométrio (E) e vilo coriônico (V). Técnica de coloração: Azul de Toluidina. Escala de Barra: $25 \mu \mathrm{m}$ 


\subsection{ESTUDO ESTEREOLÓGICO}

Os parâmetros estereológicos investigados na placenta de bovinos (Bos indicus) clonados e não clonados foram: volume referência, densidade ou fração de volume de vilos, densidade de superfície dos vilos, superfície de área dos vilos, volume star e número de unidades volume star (Figura 4).

O volume referência dos placentomas foi estimado usando o Princípio de Cavalieri. Nos animais clonados, o volume dos placentomas apresentou valor mínimo de $42,11 \mathrm{~cm}^{3}$ e máximo de 248,78 $\mathrm{cm}^{3}$ (média $=123,35 \mathrm{~cm}^{3} ; \mathrm{CE}=0,57, \mathrm{CV}=0,53$ ). Em animais não clonados, o volume do placentoma variou entre $37,84 \mathrm{~cm}^{3}$ e $140,17 \mathrm{~cm}^{3}$ (média $=98,96 \mathrm{~cm}^{3} ; \mathrm{CE}=0,58$, $\mathrm{CV}=0,38)$. Considerando-se as placentas, em bovinos clonados o volume variou de $2987,28 \mathrm{~cm}^{3}$ a $17746,56 \mathrm{~cm}^{3}$ (média $=7768,86 \mathrm{~cm}^{3} ; \mathrm{CV}=0,88$ ), já em não clonados estes valores foram de $3329,92 \mathrm{~cm}^{3}$ e $12092,96 \mathrm{~cm}^{3}$ (média $=8037,83 \mathrm{~cm}^{3} ; \mathrm{CV}=0,47$ ).

A densidade de volume dos vilos na placenta de bovinos clonados variou de 0,22 a 0,43 (média=0,30; $C V=0,32$ ), e em animais não clonados estes valores variaram entre 0,19 e 0,40 (média= 0,26; CV=0,38).

Os resultados obtidos para a densidade de superfície (Sv) dos vilos na placenta de bovinos clonados apresentaram valores mínimo e máximo de $11841,68 \mathrm{~m}^{-1}$ e $12507,56 \mathrm{~m}^{-1}$ (média $=12219,87 \mathrm{~m}^{-1}, \mathrm{CV}=0,02$ ). Em animais não clonados os valores mínimo e máximo para Sv foram $11374,67 \mathrm{~m}^{-1}$ e $15696,94 \mathrm{~m}^{-1}$ (média=12337,20 $\mathrm{m}^{-1}$ e $\mathrm{CV}=0,23$ ).

Em bovinos clonados a superfície de área $(\mathrm{Sa})$ dos vilos coriônicos na placenta variou entre 37,02 $\mathrm{m}^{2}$ e 215,38 $\mathrm{m}^{2}$ (média= 94,8 $\mathrm{m}^{2} ; \mathrm{CV}=0,87$ ). Em não clonados os valores mínimo e máximo foram de 44,36 $\mathrm{m}^{2}$ e $152,13 \mathrm{~m}^{2}$, respectivamente (média=96,18 $\mathrm{m}^{2}$; CV=0,47).

O volume star foi usado para estimar o tamanho médio dos vilos coriônicos. Em bovinos clonados, encontramos valores mínimo e máximo de $526113,87 \mu \mathrm{m}^{3} ; 1257968,99 \mu \mathrm{m}^{3}$

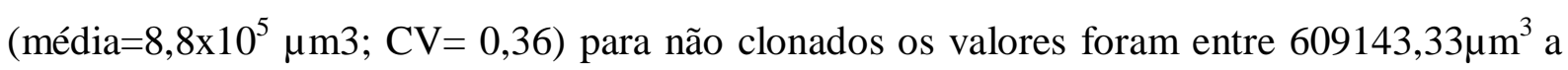
$1814143,02 \mu \mathrm{m}^{3}$ (média $=1,18 \times 10^{6} \mu \mathrm{m}^{3}, \mathrm{CV}=0,56$ ).

A respeito do volume star, foi possível determinar indiretamente, o número de vilos estimando-se o número total de unidades volume star. $\mathrm{Na}$ placenta de bovinos clonados o número de unidades volume star variou entre $1,13 \times 10^{9}$ e $6,02 \times 10^{9}$ (média= 2,61 x 109 , $\mathrm{CV}=0,88$ ); nas placentas dos bovinos não clonados os valores foram entre $1,06 \times 10^{9}$ e $3,21 \mathrm{x}$ $10^{9}$ (média $=1,88 \times 10^{9} ; \mathrm{CV}=0,49$ ). 


\subsection{EFICIÊNCIA PLACENTÁRIA}

A eficiência placentária 1 (em função do peso da placenta) nos bovinos clonados, variou entre 0,18 a 0,17 (média $=017 ; C V=0.12$ ). Já em animais não clonados a variação foi entre 0,20 a 0,24 (média $=0,22 ; \mathrm{CV}=0,07$ ).

Considerando a eficiência placentária 2 (em função da superfície de área) obteve-se valores mínimo e máximo de 0,88 e 5,87 (média=2.47; CV=0.93) em animais clonados e de 1,39 e 4,2 (média=2,64; CV=0,44) em animais não clonados.

\subsection{ANÁLISE DE CORRELAÇÃO}

Ao analisar as correlações em placentas de clonados verificamos que os parâmetros número de placentomas, eficiência placentária 2, densidade de volume, superfície de área e unidade volume star unit, obtiveram altas correlações positivas $\left(r^{2}>0.7\right)$ com o volume referência, sendo o $\mathrm{r}^{2}=0.78 ; \mathrm{r}^{2}=0.97 ; \mathrm{r}^{2}=0.88, \mathrm{r}^{2}=0.99$ e $\mathrm{r}^{2}=0.99$, respectivamente. Já em animais não clonados, apenas o peso do feto obteve $r^{2}$ acima de $0.7\left(r^{2}=0.94\right)$. 


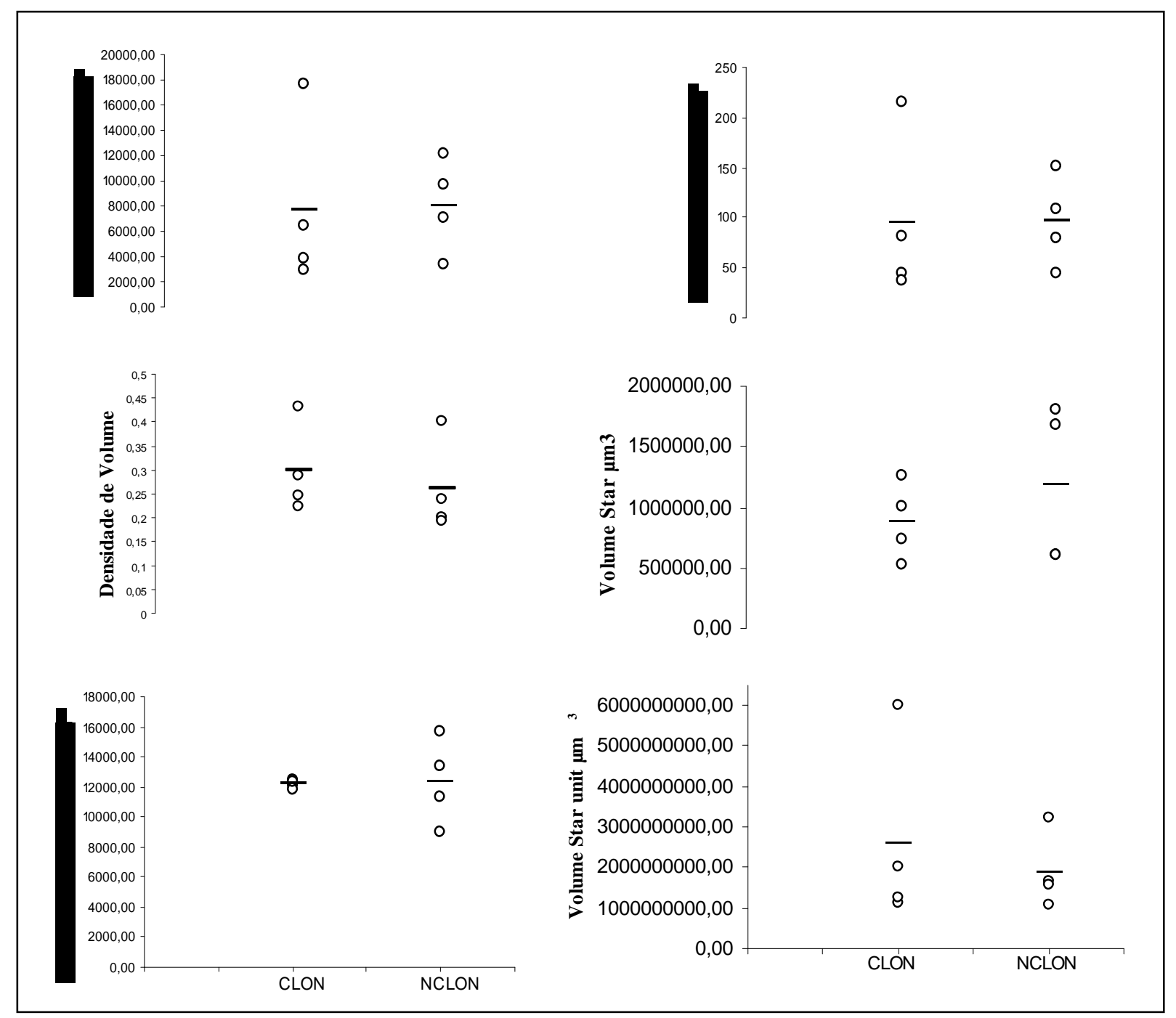

Figure 4 - Representação gráfica dos aspectos quantitativos da placenta de bovinos clonados e não clonados, sistematizando os parâmetros estereológicos investigados: volume referência, densidade de volume, densidade de superfície, superfície de área, star volume e número de unidades volume star. Os valores individuais dentro de cada grupo são representados por círculos (o) e as médias assinaladas por meio de traços $(-)$ 

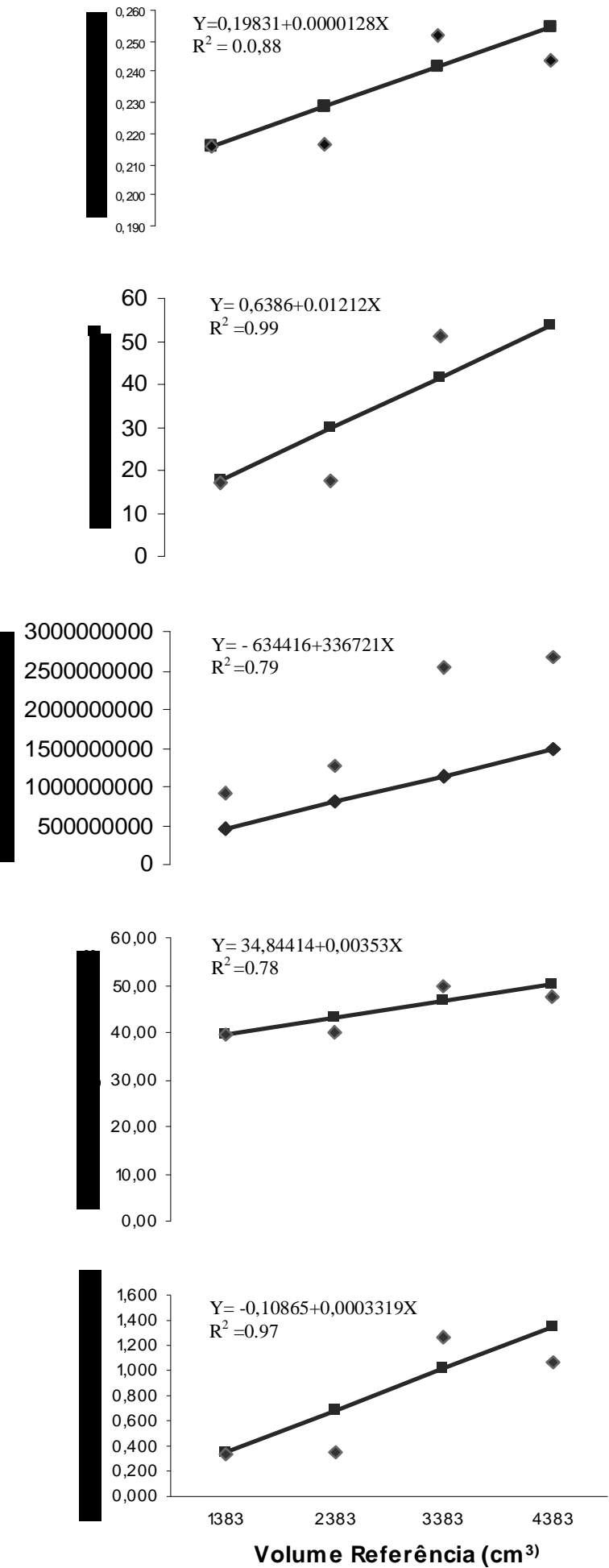

Figura 5 - O Gráfico representa o comportamento da função de regressão linear entre volume referência, densidade de volume, superfície de área, número de unidades volume star, número de placentomas e eficiência da placenta 2 na placenta de bovinos clonados. Os valores estimados em nossos resultados estão representados por quadrados ( $\square$ ) enquanto que os valores preditos são assinalados por losangos ( $)$ 


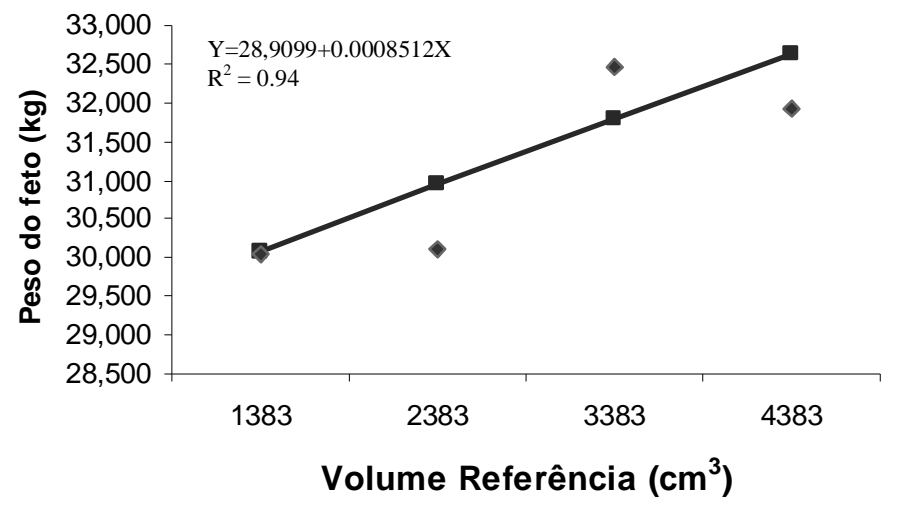

Figura 6 - O Gráfico representa o comportamento da função de regressão linear entre o volume referência e o peso do feto (PF) para a placenta de bovinos não clonados. Os valores estimados em nossos resultados estão representados por quadrados ( $\square$ ) enquanto que os valores preditos são assinalados por losangos $(\diamond)$ 


\section{Discussão}




\section{DISCUSSÃO}

Assim como nos resultados, agruparemos a discussão por tópicos, a saber: aspectos macromorfométricos; aspectos histológicos, estudo estereológico.

\subsection{ASPECTOS MACROSCÓPICOS}

Considerando o número total dos placentomas presentes na placenta verificamos que em bovinos não clonados este número encontra-se maior (42\%) em relação aos clonados, embora esta diferença não tenha sido significativa $(\mathrm{p}=0.107)$. Este resultado confirma aquele verificado por Miglino et al. (2003a) e Miglino et al. (2003b) que reportam diferenças entre o número de placentomas de clones (39) e não clonados (84). No entanto, estes autores citam que o número de placentomas em não clonados é maior (133\%) em relação aos clonados, proporção esta menor em nossas amostras.

O peso dos placentomas foi maior em clonados $(25,8 \%)$ em relação aos não clonados, no entanto quando consideramos o peso da placenta verificamos que há uma inversão de valores, ou seja, as placentas de não clonados são 2,5\% mais pesadas que as dos animais clonados. O peso dos placentomas de nossas amostras, assim como o peso das placentas de bovinos clonados e não clonados foram maiores que os valores encontrados por Laven e Peters (2001) para a mesma espécie. Verechia et. al, (2003) também estimaram o peso dos placentomas em bovinos clonados e obtiveram um valor médio de $150 \mathrm{~g}$ para os placentomas, aproximando-se da média que encontramos para clonados $(131,2 \mathrm{~g})$ em nossas amostras.

O peso da placenta também foi citado por Miles et al. (2004) ao estudar comparativamente os aspectos morfométricos da placenta de bovinos em gestação "in vivo" e "in vitro", em vacas holstein com 222 dias de gestação. Os valores foram 2,0kg para gestações in vivo e $2,5 \mathrm{~kg}$ em gestação in vitro. Hill (2001) comentou que a placenta de clones estudada por eles era recuperada intacta três horas após o parto e o seu peso estava dentro do limite normal (4,3kg). Hafez (1954) citou que durante a primeira metade da gestação ocorreu um grande crescimento dos placentomas, tanto em peso, altura, como em diâmetro, mas ele não expressou essa informação em números. Acreditamos que a razão do peso em nossas amostras ter dado maior ao que é citado na literatura está relacionado com manutenção da 
conexão materno-fetal (carúnculas/cotilédones) na pesagem. A diferença de peso entre os fetos de bovinos clonados e não clonados foi não significativa $(p=0,373)$ embora em média $o$ peso dos fetos clonados tenha sido $11 \%$ maior que o peso dos fetos de não clonados.

\subsection{ASPECTOS HISTOLÓGICOS}

Nas placentas de bovinos clonados, houve uma desorganização da disposição do endométrio, caracterizando a presença de uma árvore vilosa atípica quando comparada com a de animais não clonados. Essa desorganização também foi encontrada por Miglino et al. (2004). Em clonados há também um espaçamento mais visível entre os vilos e suas criptas, fato não comumente observado nas placentas de animais não clonados.

\subsection{ESTUDO ESTEREOLÓGICO}

A placenta humana tem sido frequentemente estudada sob o aspecto quantitativo (estereológico), (ALI, 1997; BURTON, 1997; BUSH, 2000; BURTON et al., 1996; LEE; MAYHEW, 1995; MAYHEW; SIMPSON et al., 1992; MAYHEW; SISLEY, 1998; MAYHEW et al., 2003a, 2003b; ONG et al. 2004) onde encontramos interpretações morfofuncionais para a maioria dos parâmetros estereológicos estimados para o tecido placentário. No entanto, a estereologia da placenta em bovinos ainda é restrita, embora possamos encontrar estudos em outras espécies, ratos (DRAGAN et al., 1997) camundongos (COAN et al., 2004), em eqüinos (ALLEN et al., 2002) e muares (WILSHER; ALLEN, 2003). Em bovinos não encontramos estudos com o delineamento estereológico, mas predominantemente estudos morfométricos (BERTOLINI et al., 2002; LAVEN; PETTERS, 2001; MILES, 2004; NOVIKOV et al., 2000).

\subsubsection{Volume Referência (Volume dos Placentomas e da Placenta)}


Ao analisarmos os placentomas separadamente, a estimativa do volume em clonados foi maior $(1,25 \mathrm{x})$ em relação aos não clonados. No entanto, quando consideramos toda a placenta, percebemos que os valores se inverteram, ou seja, a placenta de animais não clonados apresentou uma aumento de $1.05 \mathrm{x}$ em relação a de clonados, isso pode ser explicado pelo fato das placentas de não clonados apresentarem um maior número de placentomas $(1,41 \mathrm{x})$ do que a placenta de clonados. No entanto, estas diferenças foram não significativas tanto para os placentomas $(\mathrm{p}=0.399)$, quanto para a placenta $(\mathrm{p}=0.948)$.

O volume das placentas de bovinos não clonados (estimado pelo Principio de Cavalieri) foi maior $(8,4 \%)$ do que o volume da placenta de bovinos clonados, mas essa diferença foi não significativa $(\mathrm{p}=0,947)$. Este parâmetro não tinha sido estimado em bovinos por métodos estereológicos e somente o peso da placenta era reportado na literatura (BJORKMAN, 1954; HILL, 2001; MILES et al., 2007)

Em placentas de mulheres, Lee e Mayhew (1995) verificaram em dois tipos de grupo étnicos (americanas e não indianas) que a altitude interferiu no volume placentário, ou seja, com o aumento da altitude o volume placentário aumentou em 6,3\% nas mulheres americanas e em 4,2\% nas mulheres não indianas. Fazendo uma comparação entre espécies, o volume da placenta nos bovinos clonados foi maior $(17,9 \mathrm{x})$ em relação à placenta humana em altitude baixa e de 17,3x em relação a alta altitude. Já em não clonados esse aumento chegou a 18,6x e 17,9x em altitudes baixas e elevadas, respectivamente. Considerando as etnias (americanas e não indianas) em baixas altitudes as diferenças foram respectivamente, de 18x e 18,1x em relação aos clonados e respectivamente de 18,68x e 18,72x em relação aos não clonados. No entanto, em altitudes elevadas, as diferenças foram de 17x e 17,4x em clonados e 17,6 e 17,9x em não clonados, respectivamente. Se a altitude e diferenças no volume placentário em humanos, é possivelmente que estas diferenças ocorram nas placentas de bovinos, mas nenhum dado sobre esse assunto foi encontrado na literatura.

\subsubsection{Densidade de Volume dos Vilos Coriônicos}


Embora não significativo ( $\mathrm{p}=0,593)$, a densidade de volume dos vilos na placenta de animais clonados foi maior (14,2\%) quando comparada à de não clonados. Miles et. al. (2004) ao estudar gestações de bovinos "in vivo" e "in vitro", verificaram que a densidade de volume dos vilos coriônicos nos animais "in vivo" foi de 0,59 e "in vitro" 0,53 . Nossos resultados diferiram d encontrado por estes autores, uma vez que a densidade de volume da placenta foi de 0.26 para clonados e de 0.30 para não clonados. Em placentas de bovinos clonados o nosso resultado foi inferior (1.97x e 1.77x) ao comparar com o mencionado para gestação "in vivo" e "in vitro" respectivamente. Em não clonados essa diferença foi de 2,3x e 2x normal Este parâmetro permitiu-nos estimar o volume total que os vilos ocuparam na placenta, logo, em placentas de bovinos clonados os vilos ocuparam uma maior $(1,15 x)$ fração de volume, embora esta diferença fosse não significativa $(\mathrm{p}=0.593)$.

\subsubsection{Densidade de Superfície (Sv)}

A densidade de superfície (Sv) dos vilos na placenta foi próxima (1\%) em animais clonados e não clonados sendo os resultados não significativos $(\mathrm{p}=0.938)$. Conclusões baseadas apenas na Sv não são válidas "Reference Trap" (Mayhew et al., 20032b) uma vez que se faz necessário mensurar o espaço referência para então estimar a área de superfície que é um parâmetro mais acurado, pois utiliza a densidade de superfície e o volume referência para obter a área de superfície total ocupada pelos vilos na placenta.

\subsection{4 Área de Superfície (Sa)}

Este parâmetro nos permite verificar a área de superfície total ocupada pelos vilos na placenta. Em nossas análises observamos que área ocupada pelos vilos nas placentas de animais não clonados é maior (1.5\%) quando comparada aos bovinos clonados. Esse resultado embora não significativo $(\mathrm{p}=0.978)$, sugere que os vilos da placenta de não clonados apresentam uma discrição mais ampla. Miles et. al. (2004) ao estudarem gestações "in vivo" e "in vitro" de bovinos, estimaram a superfície de área do útero em $2.161 \mathrm{~cm}^{2}$, embora estes autores não mencionarem o método estereológico utilizado. Estes autores basearam-se seus 
métodos quantitativos nas proposições de Weibel (1979), este é um autor respeitado por suas contribuições para a estereologia, no entanto seus métodos estereológicos de quantificação já estão ultrapassados, tendo em vista que este autor não utiliza amostras isotrópicas tridimensionais e sistematicamente aleatórias para a obtenção da amostragem.

\subsubsection{Volume Star e Número de Unidades Volume Star}

$\mathrm{Na}$ placenta de bovinos não clonados os vilos coriônicos são maiores (34\%) comparados aos de clonados. A partir do volume star foi possível estimar indiretamente o número total de vilos da placenta. O número destes vilos na placenta de bovinos clonados foi maior em 39\% ao encontrado em placentas de não clonados. Do ponto de vista global, o tamanho dos vilos na placenta foi proporcional ao número destes, uma vez que em animais não clonados estes vilos são maiores $(1,34 \mathrm{x})$, mas perfazem um menor número total $(1,39 \mathrm{x})$. Embora estas diferenças, foram não significativas para o volume star $(p=0,446)$ e para o número de unidades volume star $(\mathrm{p}=0,577)$.

O tamanho dos vilos coriônicos bem como o seu número não tem sido reportado na placenta de animais, embora sejam amplamente investigados em placentas humanas (BARKER, 2001; BURTON, et al., 1989, BURTON, et al., 1996; CASTELLUCCI et al., 2000; MAYHEW, 1991; MAYHEW, 2002; MAYHEW, 2003; MAYHEW; 1986; MAYHEW et al., 2003; MAYHEW et al., 2004). Em humanos Mayhew e Wadrop (1994) estimaram o volume star da placenta de mulheres em diferentes fases da gestação. Observamos o fato de que o tamanho dos vilos nestas placentas $\left(1.47 \times 10^{6} \mu \mathrm{m}^{3}\right)$ foi apenas $(1,2 \mathrm{x})$ maior ao verificado em placentas de bovinos não clonados $\left(1.18 \times 10^{6} \mu \mathrm{m}^{3}\right)$ e $(1,7 \mathrm{x})$ maior em relação aos clonados $\left(0,88 \times 10^{6} \mu \mathrm{m}^{3}\right)$.

\subsection{EFICIÊNCIA DA PLACENTA}


A eficiência placentária foi estimada usando três variáveis diferentes, o peso da placenta, a Superfície de área ocupada pelos vilos e o peso do feto ao nascimento. Em nossos resultados a eficiência placentária (relação entre peso da placenta pelo peso do feto) de bovinos não clonados apresentou-se significativamente maior (28\%) em relação aos clonados $(\mathrm{p}=0,0134)$. Esta eficiência está diretamente relacionada com o peso da placenta e indiretamente relacionada ao peso do feto, como afirmou Mayhew ${ }^{1}$ (2006) (Informação pessoal), diferente do foi citado na literatura por Dawy et al. (2005); Mesa et al. (2005); Miles et. al. (2004); Miles et al. (2005) e Vonnahme et al. (2002), que utilizaram uma relação oposta, onde a eficiência é calculada dividindo o peso do feto pelo peso da placenta, considerando o peso do feto como parâmetro mais importante para a eficiência placentária.

Como em clonados as altas taxas de mortalidade observadas no estágio inicial e final da gestação, abortos, má formação fetal, mortalidade ao nascimento, anormalidades de desenvolvimento, estão associadas com a má formação placentária (Hill, 2001), nossos resultados em relação à eficiência placentária (EP1) corroboram com o que foi reportado por este autor.

\subsection{CORRELAÇÃO ENTRE VOLUME DA PLACENTA E DEMAIS PARÂMETROS QUANTITATIVOS}

A análise de regressão linear nos permitiu obter altas correlações entre o volume da placenta e o número de placentomas $\left(r^{2}=0,78\right)$, eficiência placentária $2\left(r^{2}=0,97\right)$, densidade de volume $\left(r^{2}=0.88\right)$, superfície de área $\left(r^{2}=0.99\right)$ e número de unidades volume star $\left(r^{2}=0.99\right)$ na placenta de bovinos clonados. Na placenta de bovinos não clonados a correlação foi alta para a variável peso do feto $\left(r^{2}=0.94\right)$ em relação ao volume da placenta. Desta forma o tamanho da placenta nos clonados está diretamente correlacionado com o número de placentomas, enquanto que nos animais não clonados esta correlação se faz com o peso do feto.

A densidade de volume dos vilos coriônicos da placenta de clonados também acompanha o aumento ou diminuição do volume placentário. Nas placentas de clonados o nún 1-Informação fornecida por Terry Mayhew em Nottingham, UK, 2006

ar entre eles

o volume da placenta uma vez que eles tiveram uma correlação muito alta $\left(\mathrm{r}^{2}=0.99\right)$, caracterizando que qualquer alteração no volume da placenta será acompanhada por alterações correspondentes no número total de vilos coriônicos. 
Com estas correlações é possível predizer que em placentas de bovinos clonados, por exemplo, o aumento no volume da placenta aumentaria a superfície de área e o número de unidades volume star nas mesmas proporções, já em não clonados o aumento do volume da placenta em $3 \mathrm{~cm}^{3}$, por exemplo, aumentaria o peso do feto em $2.82 \mathrm{~g}$. Neste último caso, o aumento ocorreria em $94 \%$ dos casos. 


\section{Conclusões}




\section{CONCLUSÕES}

Os resultados obtidos no presente estudo, com delineamento estereológico de covariância ou de segunda ordem, permitiram-nos concluir que:

A placenta de bovinos clonados apresenta um número total de placentomas menor que a de não clonados.

O número estimado de vilos coriônicos na placenta de animais clonados é maior em relação aos não clonados, porém estes vilos são menores em relação aos bovinos não clonados.

Os vilos coriônicos ocupam uma maior área de superfície na placenta de bovinos não clonados.

Quando se considera o peso da placenta, esta foi mais eficiente nos animais não clonados. 
Referências 


\section{REFERÊNCIAS}

ABDEL-RAOUF, M.; BADAWI, H. M. Morphological study of the uterine Egyptian buffalo cows. Zentralblatt für Veterinärmedizin A, v.13, n.1, p. 252-263, 1966.

ACHARYA, R. M.; KOHLI, M. L. Studis on bovine fetal placenta: II-Relationship among wight of placenta, number of cotyledons and birth weight of calf in Hatyana catte. Journal of Research of Punjab Agriculture University of Hissar, v. 5, n. 1, p. 99-102, 1968.

ALI, K. Z. M. Stereology study of the effect of altitude on the trophoblast cell populations of human term placental villi. Placenta, v. 18, p. 447-450, 1997.

ALLEN, W. R.; WILSHER, S.; TURNBULL, C.; STEWART, F; OUSEY, J.; ROSSDALE, P. D; FOWDEN, A. L. Influence of maternal size on placental, fetal and postnatal growth in the horse. I.Development in utero. Reproduction, v. 123, p. 445-453. 2002

AMBRÓSIO, C. E. A barreira placentária em cães (Canis familiaris, Linnaeus, 1758): Fluxo sanguíneo materno-fetal. 2003. 48 p. Tese (doutorado em Medicina Veterinária) Faculdade de Medicina Veterinária e Zootecnia, Universidade de São Paulo, São Paulo, 2004.

AMOROSO, E. C. Placentation. In: PARKES, A. S. Marshall's physiology os reproicuction. 3. ed. London: Longmans, Gree, 1952. v. 2, cap. 15, p. 127-311.

BARBELLA, S. L. Consiedraciones generales sobre la gestación del chiguire (Hydrochoerus hydrochaeris). Acta Científica Venezuelana, v. 38, p. 84-89, 1987.

BARONE, R. Anatomie comparée des mamíferes domestiques. Paris: Vigot, 1976. fac. LL, p. 579-605.

BARRETO FILHO, J. B.; MARQUES JÚNIOR, A. P.; NASCIMENTO, E. F.; SANTOS, R. L. Alguns aspectos histofisiológicos do placentomas da vaca zebu (Bos taurus indicus) no pós-parto. Revista Brasileira Reprodução Animal, v. 19, n. 3-4, p. 161-164, 1995.

BERTOLINI M, MASON JB, BEAM SW, CARNEIRO GF, SWEEN ML, KOMINEK D. J, MOYER A. L; FAMULA T. R.; SAINZ R. D.; ANDERSON G. B. Morphology and morphometry of in vivo- and in vitro-produced bovine concepti from early pregnancy to term and association with high birth weights. Theriogenology, v. 58, n. 5, p. 973-94, 2002.

BHOSREKAR, M. R.; SHARMA, K. N. S. Studies on foeltal placentae of cattle and an Murrah buffaloes of different breeds. Indian Journal of animal Production, v.3, n.1, p. 8$15,1972$.

BJÖRKMAN, N. Morphological and histochemical studies on the bovine placenta Acta Anatomica, v. 22, n. 2, p. 1-92, 1954 
BJÖRKMAN, N.; SOLLÉN, N. Morphology of the bovine placenta at normal delivery Acta Veterinaria Scandinavia, v. 1, p. 347-362, 1960.

BJÖRKMAN, N. Placentation. In: DELLMAN, H. D.; BROWN, E. M. Textbook of veterinary histology. Philadelphia, US: Lea \& Febger 1987. p. 351-369.

BURTON, G. J.; MAYHEW, T. M.; ROBERTSON, L. A. Stereological Re-examination of the effects of varying oxygen tensions on human placental villi maintained in organ culture for up to 12 h. Placenta, v. 10, p. 263-273, 1989.

BURTON, G. J.; RESHETNIKOVA, A. P.; MILOVANOV, A. P.; TELESHOVA, O. V. Stereological Evaluation of vascular adaptations in human placental villi to differing forms of hypoxic stress. Placenta, v. 17, p. 49-55, 1996.

BUSH, P. G.; MAYHEW, T. M.; ABRAMOVICH, D. R.; AGGETT, P. J.; BURKE, M. D.; PAGE, K. R. A quantitative study on the effects of maternal smoking on placental morphology and cadmium concentration.Placenta, v. 21, p. 247-256, 2000.

CASTELLUCCI M, KOSAKE, G; VERDENELLI, F; HUPPERTZ B; KAUFMANN, P. Villous sprouting: fundamental mechanisms os placental development. Human Reproduction. Update, v. 6, p. 485-494. 2000.

COAN, P. M.; FERGUSON-SMITH, C.; BURTON, G. J. Developmental dynamics of the definitive mouse placenta assessed by stereology. Biol. Reprod. v.70 n. 6, p.1806-1813, 2004.

DANTZER, V. Endotheliochorial placentation. In: Knobil, E; NEILL, J. D. Encyclopedia of reproduction. San Diego: Academic Press, v.1, p. 1078-1084. 1999.

DANTZER, V.; LEISER, R.; KAUFMANN, P.; LICKHARDT, M. Comparative morphological asprects of placental vascularization. Trofoblast Research, v. 3, p. 2356-260, 1988.

DAVIES, J.; WINSATT, W. A. Observation on the fine structure of the sheep placneta. Acta Anatomica, v. 65, p. 182-223, 1966.

DRAGAN Y P.; CAMPBELL H. A.; XU X. H.; PITOT, H. C. Quantitative stereological studies of a 'selection' protocol of hepatocarcinogenesis following initiation in neonatal male and female rats. Carcinogenesis, v. 18, n. 1 p. 149-158, 1997.

DRIEUX, H.; THIÉRY, G. La placentation chez les mamiferos domestiques III. Placenta des Bovidés. Recueil de Médecine Vétérinaire, v. 127, n. 1, p. 5-25, 1951.

DUFTY, J. H. Clinical srudies on the fopetal membranes of Hereford cattle. Australian Veterinary Journal, v. 50, n. 5, p. 181-184, 1974.

ENRIQUEZ-YAP, E. L. The placentome of the philippine carabao (Bubalus bubalis) In midpregnancy: am study to stablish the basis of clinico-pathological analysis on the possible causes of esrly reproductive failures. The Philippine journal of Veterinary Medicine, v. 13, n. 1-2, p. 1-25, 1974. 
FEITOSA-JÚNIOR, F. S. Pesquisa anatômica sobre ramificação e distribuição das artérias e veias da placenta de búfalas. 1997. 237 p.Tese (doutorado)- Faculdade de Medicina Veterinária e Zootecnia da universidade de São Paulo, São Paulo, 1997.

FRANDSON, T. D. Anatomy and physiology of farm animals. 4.ed. Philadelfhia: Lea \& Febiger, 1986. p. 427-430.

BORDIGNON, V.; SMITH, L. C.. Clonagem animal por transferência nuclear. In: GONÇALVES, P. B. D.; FIGUEIREDO, J. R.; FREITAS, V. J. F. Biotécnicas aplicadas a reprodução animal 1. ed. São Paulo: Varela, p. 281-295, 2001.

GUNDERSEN H.J.G.\& JENSEN, E.B.; The efficiency of systematic sampling and its prediction. Journal of Microscopic, v.147, p. 229-263.1987.

HAFEZ, S. The placentome in the buffalo. Acta Zoologie, v. 35, n. 1-2, p.177-191, 1954.

HAFEZ, A.S. E. Reprodução animal. São Paulo: Manole, 1982. 582p.: Gestação, Fisiologia Pré-natal e Parto.

HILL J. R, EDWARDS, .J. F.; SAWYER, N.; BLACKWELL, C. ;CIBELLI, J.B. Placental anomalies in a viable clone calf. Cloning .dec, 2001.

HILL J. T; BURGHARDT R.C.; JONES K.; LONG C.R.; LOONEY C. T.; SHIN T.; SPENCER T.E.; THOMPSON, J. A.; WINGER, Q. A.; WESTHUSIN, M. E. Evidence for placental abnormality as the major cause of mortality in fist-trimester somatic cell cloned bovine fetuses. Biology of reproduction, v. 63, n.6, p. 1787-1794, 2000.

HRADECKY, P.; MOSSMAN, H. W.; STOTT, G. G. Comparative developmente of ruminant placentomes. Theriogenology, v.29, n.3, p. 715-729, 1988.

JAINUDEEN, M. R, HAFEZ, E. S. E. Gestação, fisiologia pré-natal e parto. In HAFEZ, E.S.E. Reprodução Animal. 6. ed. P. 141-155, São Paulo: Manole, 1995.

JENKINSON, J. W. Vertebrate embriology. London: Oxford University Press, 1925, p. 193232.

KADU, M. S.; KAIKINI, A. S. Studies on foetal placenta in Sahiwal cows. Indian Veterinary journal, v. 52, n. 1, p. 6-11, 1974.

KATHIRESAN, R.; RAJASUNDARAM, R. C. ; PATTABIRAMAM, S. R. Histological and histochemical changes in the endometrium and placenta during different stages of gestation in buffaloes (Bubalus bubalis). Indian Veterinary Journal, v. 69, p. 326-328, 1992.

KAUFMANN, P. Electron microscopy of the guinea-pig placental membranas. Placenta, p. 3-10, 1981. Supplement 2.

KAUFMANN, P.; BURTON, G. Anatomy and genesis of the placenta. In KNOPBIL, E.; NEIL, J. D. The physiology of reproduction. 2. ed. New York: Raven, 1994. v.1, cap. 8, p. 441-484.

KING, B. F. Comparative anatomy of placental barrier. Bibliotheca Anatomica (Karger, Basel), n. 22, p. 13-28,1982. 
KING, G. J.; ATKINSON, B.A. The bovine intercaruncular placenta throughout gestation. Animal Reproduction Science, v. 12, p. 241-254, 1987.

KING, G. J.; ATKINSON, B. A.; ROBERTSON, H. A. Development of the bovine placentome from days 20 to 29 of gestation. Journal of Reproduction and Fertility, v. 59, p. $95-100,1980$.

KINGMAN, H. E. The placentome of the cow. American Journal of Veterinary Research. v. 9 , n. 30, p. 125-130, 1948.

LAMMING, G. E. Marshall's physiology of reproduction. London: Chapman \& Hall, 1994, v. 3, 367 p.

LATSHAW, W. K. Extraembryonic membranes and placentation. In: Veterinary developmental anatomy- a clinical developmental. Toronto: Becker, 1987, cap.5. p. 49-74.

LAVEN, R. A.; PETERS A. R. Gross morphometry of the bovine placentoma during gestation. Reproduction Domestic Animal. v. 36. p. 289-296, 2001.

LEE, R.; MAYHEW, T. M. Star volumes of villi and intervillous pores in placentae from low and high altitude pregnancies. Journal Anatomy, v. 186, p.349-355, 1995.

LEISER, R.; ENDERS, A. C. Light and electron-microscopic study of the near-term paraplacenta of the domestic cat, I. Polar zone and paraplacental junctional areas. Acta Anatomy, v. 106, p. 293-311, 1980.

LEISER, R.; KAUFAMANN, P. Placental Structure: in a comparative aspect. Experimental Clinical Endocrinology, v. 102. 1994.

LEISER, R.; KREBS, C.; EBERT, B.; DANTZER, V. Placental vascular corrosion cast studies a comparison between ruminants and humans. Microscopy Research and Technique, v. 38, p. 76-87, 1997b

LEISER, R.; KREBS, C.; KLISCH, K.; EBERT, B.; DANTZER, V.; SCHULER, G.; HOFFMANN, B. Fetal vilosity and microvasculature of the bovine placentome in the second half of gestation. Journal of Anatomy, v. 191, p. 571-527, 1997a.

LEISER, R.; KOOB, B. Development and characteristics of placentation in a carnivore, the domestic cat. The journal of Experimental Zoology, v.26, p.642-656, 1993.

LEISER, R.; PFARRER, C.; ABD-ELNAEIM, M.; DANTZER, V. Feto-maternal anchorage in epitheliochorial and endothelial placental types studied by histology and microsvascular corrosion casts. Trophoblast Research, v. 12, p. 21-39, 1998

LÓPEZ, S. Caracterización preliminar de la gestación en chiguire (Hydrochoeros hydrochaeris). Boletín del informe anual del IPA, p. 18-19, 1981.

MALARD, J. B. BARRETO FILHO, R. L.; MARQUES JÚNIOR, A. P. Proporção volumétrica dos componentes estruturais da placenta de vacas zebu ao longo da gestação.

Arquivo Brasileiro de Medicina Veterinária e Zootecnia, v. 48, n. 5, p. 553-558, 1996. 
MARQUES JÚNIOR, A. P.; ANDRADE, J. S.; BARRETO FILHO, J. B. Histologia da placenta da cabra (Capra hircus). . Arquivo Brasileiro de Medicina Veterinária e Zootecnia, v. 44, n. 1, p. 43-48, 1992.

MARQUES JUNIOR, P.; BARRETO FILHO, J. B.; SATURNINO, H. M. Morphometric aspects of the placenta of Zebu cows (Bos Taurus indicus ). Arquivos Brasileiros de Medicina Veterinária e Zootecnia, v.45, n. 2, p. 213-219, 1993.

MARSHALL, F. H. A. Marshall's physiology of reproduction. 3 ed. London: A. S. Parkes, Longman's Greeen, 1952. p. 189-211.

MATAMOROS, Y. Anatomia e histologia del sistema Reprodutcor del tepezcuinte (cuniculus paca). Revista de Biologia Tropical, v. 29, n. 1, p.155-164, 1981.

MATTFELDT, T., MALL, G.; GHAREHBAGHI, H. \& MÖLLER, P. Estimation of surface area and length with the orientator. Journal of Microscopy. 159, p. 301-317.1990

MAYHEW, T. M. Changes in fetal capillaries during preplacental hypoxia: growth, shape remodeling and villous capillarization in placentae from high-altitude pregnancies. Placenta, v. 24, p. 191-198, 2003.

MAYHEW, T. M. Fetoplacental angiogenesis during gestation is biphasic, longitudinal and occurs by proliferation and remodelling of vascular endothelial cells. Placenta, v. 23, p. 742$750,2002$.

MAYHEW, T. M. Microscopical morphology of the human placenta and its effects on oxygen diffusion: a morphometric model. Placenta. v. 7, n.2. p.121-131. 1986.

MAYHEW, T. M. The surface area of an object revisited- but from random directions. Journal Theriogenology Biology, v.144, p. 259-265, 1990.

MAYHEW, T. M. Villous Trophoblast: Morphometric perspectives on growth, differentiation, turnover and deposition of fibrin-type fibrinoid during gestation. Placenta. V. 22, p. 628-638. 2001.

MAYHEW, T. M. The new stereological methods for interpreting functional morphology from slices of cells and organs. Experimental Biology, v.76, p.639-665. 1991.

MAYHEW, T. M.; BAKER, P. N. Villous Trophoblast: morphometric Perspectives on Growth, differentiation, Turnover and deposition of fibrin-type fibrinoid during gestation. Placenta, v. 22, p. 628-638, 2001.

MAYHEW, T. M, BURTON, G.; Stereology and its impact on our understanding of human placental functional morphology. Microscopy Research and Technique, v. 38, p. 195-205, 1997.

MAYHEW, T. M. CHARNOCK-JONES, D. S.; KAUFMANN, P. Aspects of human fetoplacental vasculogenesis and angiogenesis. III. Changes in complicated pregnancies. Placenta. v. 25, p.127-139, 2004. 
MAYHEW, T. M.; HUPPERTZ, B.; KAUFMANN, P.; KINGDOM, J. C. P. The reference trap revisited: Examples of the dangers in using ratios to describe fetoplacental angiogenesis and trophoblast turnover. Placenta, v. 24, p. 1-7, 2003 b.

MAYHEW, T. M.; OHADIKE, C.; BAKER, P. N.; CROCKER, I.P.; MITCHELL, C.; ONG, S.S. stereological investigation of placental morphology in pregnancies complicated by preeclampsia whit and without intrauterine growth restriction. Placenta, v.24, p. 219-226, 2003 a.

MAYHEW, T.M.; SISLEY, I. Quantitative studies on the villi, trofoblast and intervillous pores of placentae for womem with well-controlled diabetes mellitus. Placenta, v.19, p.371377, 1998.

MAYHEW, T. M.; WADROP, E. Placental morphogenesis and the star volumes of villous trees and intervillous pores. Placenta, v.15, p.209-217, 1994.

MIGLINO, M.A. Pesquisa anatômica sobre a ramificação e distribuição das artérias e veias da placenta de bovinos. São Paulo, 1991. 303p. Tese (Livre Docência) Faculdade de Medicina Veterinária e Zootecnia, Universidade de São Paulo.

MIGLINO, M. A. PEREIRA, F. T.V; BRAGA, F.C. ; ASSIS NETO, A. C.; AMBRÓSIO, C.E.; KFOURY, R. J.; OLIVEIRA, L. J.; PAPA, P. C.; CARVALHO,A.F.; SANTOS, T.C VISITIN, J.A.; MELLO, M.R.B.; GARCIA, J.M.; YAMAZAKI,W.; RUMPF, R.; IGUMA, L.; CARTER, A.M.; LEISER,R.; Placentation in the cloned cattle. In: International Congresso $\mathrm{n}$ animals Reproduction, 15., 2004, Porto Seguro. Anais...v. 2, p. 570.

MIGLINO, M. A. VERECHIA, F. T.; VISITIN, J.A.; MELLO, M. R. B.; GARCIA, J. M.; YAMAZAKI, W.; AMBRÓSIO, C. E.; CARVALHO,A. F.; BRAGA, F.C.; SANTOS, T.C.; LEISER, R.; CARTER, A. M.; Placentação em bovinos clonados: arquitetura microvascular e estrutura. Acta scientiae veterinarie. Supl. 31, p.484-485, 2003a

MIGLINO, M. A. VERECHIA, F. T.; VISITIN, J.A.; MELLO, M. R. B.; GARCIA, J. M.; YAMAZAKI, W.; AMBRÓSIO, C. E.; CARVALHO,A. F.; BRAGA, F. C.; SANTOS, T. C.; LEISER, R.; CARTER, A. M. Cloned cattle placentation: microvascular arquitecture and structure. Placenta, v.37, n.113.p 484-485, 2003 b.

MILES, J. R.; FARIN, C. E.; RODRIGUES K. F.; ALEXANDER, J. E.; FARIN, P. W. Angiogenesis and morphometry of bovine placentas in late gestation from embryos produced in vivo or in vitro. Biology of Reproduction, v. 71, n. 6 p.129-26, 2004.

MOSSMAN, H. W.; STRAUSS, F. The fetal membranes of the pocket gopher illustrating an intermediate type of rodent membrane formation. from the beginning of the allantoid to term. The American journal of anatomy, v. 113, n. 3, p. 447-477, 1963.

MURAI, T.; YAMAUCHI, S. Erythrophagocytosis by the trophoblast in a bovine placentome. The Japanese Journal of Veterinary Science, v. 48, n. 1, p. 74-87, 1986.

MYGKAYA, G.; VREELING-SINDELAROVA, H. Erythrophagocytosis by cells of the trofoblastic epithelium in the sheep placenta in different stages of pregnancy. Acta Anatomica, v. 95, p. 234-248, 1976. 
NODEM, D. M.; DE LAHUNTA, A. Embriologia de los animales domésticos. Espanha: Acribia, 1990. cap. 3 , 399 p.

NOVIKOV, V. D; MASHAK S. V.; BACHURINA T. V. The structural manifestations of the adaptive mechanisms occurring in the villous placenta during gestosis. Morfologia, v.117, n.2 p. $72-5,2000$

ONG, S. S.; TYLER, D. J.; MOORE, R. J.; GOWLAND, P. A.; BAKER, P. N.; JOHNSON, R. I.; MAYHEW, T. M. Functional magnetic resonance imaging (Magnetization transfer0 and stereological analysis of human placenta in normal pregnancy and in pre-eclampsia and intrauterine growth restriction. Placenta, v. 25, p. 408-412, 1004.

PAVAUX, C. A color Atlas of bovine visceral anatomy. [S.1.]: Wolf Medical, 1983. p. 120121.

PELAGALLI, G. V.; MATRONARDI, M.; POTENA, A. La circulazione placentare in alcuni ruminanti. Acta Medica Veterinária, v. 19, n. I/II, p. 3-31, 1973.

PEREIRA, F. T. V. Eritrofagocitose no trofoblasto bufalino (Bubalus bubalis bubalisSimpson,1945). 2003. 102 p. Tese (Doutorado) - Faculdade de Medicina veterinária e zootecnia da Universidade de São Paulo, São Paulo, 2003.

PEREIRA, F. T. V. Desenvolvimento do placentônio em búfalos (Bubalus bubalis bubalis Linnaeus, 1758). 2000. 76p Tese (Mestrado) - Faculdade de Medicina Veterinária e Zootecnia da Universidade de São Paulo, São Paulo, 2000.

PERRY, J. S. The mammalian fetal membranes. Journal of Reproduction and Fertility, v. 62, p.321-335, 1981.

PINTO, L. M. Caracterização da célula binucleada na placenta de vacas nelore (Bos indicus- Linnaeus, 1758). 2002. 87p. Tese (doutorado) - Faculdade de Medicina Veterinária da Universidade de São Paulo, São Paulo, 2002.

PURBEY, L. N; SANE C. R. Studies on the process of parturition and morphology of placenta in dangi cows. Indian Journal of Animal Health, v. 16, n. 1, p. 25-29, 1977.

RAM, R.; CHANDRA, G. Macroscopic studies on the placenta of buffalo (Bubalus bubalus). Indian Veterinary Journal, v. 61,n. 6. p. 458-462, 1984.

ROBERTS, S. J. Veterinary obstetrics and genital diseases (theriogenology). 3. ed. Ann Arbor: Edwards Brothers, 1986. p. 19-27.

SANTOS, H. S. L. Embriologia comparada: texto e Atlas. Jaboticabal: FUNEP, 1996. p. 189.

STATISTICAL ANALISYS SYSTEM. SAS user's guide: statistics. basic and statistic. Cary: SAS, 1995. $1.686 \mathrm{p}$.

SCHOENAU, L. S F. Aspectos anatômicos da macro e microvascularização da placenta em ovinos lanados. 2000. 133p. Tese ( Doutorado) - Faculdade de Medicina Veterinária da Universidade de São Paulo, São Paulo, 2000. 
SCHWARZE, E.; SCHRÖDER, L. Compêndio de anatomia veterinária e embriologia. Zaragoza: Acriba, 1970. v. 6, p. 88, 89, 240 - 243.

SHARMA, R. D.; NANDA, B. S.; SAIGAL, R. P.; KHATRA, G. S.; GUPTA, S. K. Histomorphological and histochemical studies of placentome and expelled foetal membranes of buffalo. Indian Journal animal Science, v. 53, n. 9, p. 964-967, 1983.

SHARMA, R. D.; GUPTA, S. K.; KOHLI, R. N. Morphological studies on foetal membranes in Murrah buffaloes. Indian Journal of Dairy Science, v. 32, n. 1, p. 1-6, 1979.

SHARMA, R. D.; NANDA, B. S.; SAIGAL, R. P.; KHATRA, G. D.; GUPTA, S. K. Note on histological and histochemical study of accessory cotyledons of buffalo. Indian Journal of Dairy Science, v. 52, n. 4, p. 261-263, 1982.

SCHLAFER, D. H.; FISHER P. J.; DAVIES, C. J. The bovine placenta before and after birth: placental development and function in health and disease. Animal Reproduction Science, p. 60-61, 2000.

SILVA, D. F. P; MORAIS-PINTO, L.; SANTOS, T. C.; MIGLINO, M. A. Aspectos macroscópicos e vascularização da placenta e do cordão umbilical de bovinos da raça nelore.

Revista Brasileira de Reprodução Animal. v. 28, n. 5, p. 256-267, 2004.

SIMPSON, R. A.; MAYHEW, T. M.; BARNES, P. R. From 13 weeks to term, the trophoblast of human placenta grows by the continuous recruitment of new proliferative units: A study of nuclear number using the disector. Placenta, v 13, p. 501-512, 1992

SKINNER, Henry A. The origin of medical terms, 2. ed. Baltimore: Williams \& Wilkins, 1961, p. 328.

SLOSS, V.; DUFTY, J. H. Handbook of bovine obstetrics. Baltimore: Williams \& Wilkins, 1980. p. 25-27.

SOIRON, M. L. Das siidamerikanische wasserschwein (Hydrochoeros hydrochaeris, L. 1766). Physiologisch- Anatomische und Klinische untersuchungen unter dem aspect der versuchstierkundlichen eignung. 1993. 133p.- Fachberich veterinârmedizin, Justus- LiebingUniversitát giessen, Giessen, 1993.

STEVEN, D. H. Anatomy of the placental barrier. In: Comparative placentation: essays in structure and function. London; Academic, 1975. cap. 3. p. 58-86.

STEVEN, D. H. Interespecies differences in the structure and function of trophoblast. In: WHITE, A.; LOKE, Y. M. Biology of trophoblast. Amsterdam: Elsevier, 1984, 706 p.

STICKLAND, N. C.; PURTON, M. D. A quantitative evaluation of placentome development in Zebu cattle (bos indicus). Zentralblatt für Veteriärmedizin C- Anatomica Histologica Enbryologica, v. 6, n. 1, p. 81-86, 1977.

STOFFEL, M. H.; GILLE, U.; FRIESS, A. E. Scanning electros microscopy of the canine placenta. In: MOTTA, P. M. Progress in clinical and biological research: new trends in microanatomy of reproduction. New York: Alan Liss, 1998. v. 103, n.4. p.293-300.

TORRINHA, F. Dicionário latino-português. 3. ed. Porto: Gráficos Reunidos Ltda., 1942 
VERECHIA, F. T.; MIGLINO, M. A .; VISINTIN, M. B.; MANSANO, J.; YAMASAKI, W.; AMBRÓSIO, C. E; CARVALHO,A .F..; BRAGA F. C.; SANTOS, T. C.; LEISER, R.

Placentação em bovinos clonados: arquitetura microvascularização e estrutura. In: CONGRESSO DE INTEGRAÇÃO EM BIOLOGIA DA REPRODUÇÃO, 2003. Ribeirão Preto. Anais....[Ribeirão Preto]: [s. n], 2003.

WILSHER S.; ALLEN W. R.. The effects of maternal age and parity on placental and fetal development in the mare. Equine Vet J. v. 35, n. 5 p. 476-83, 2003

WINSATT, W. A. New histological observations on the placenta of the sheep. The American journal of anatomy. , v. 87, p. 391-458, 1950.

WINSATT, W. A. Observations on the morphogenesis, cytochemistry, and significance of the binucleated giant cells of the placenta of ruminants. The American journal of anatomy, v.159, n. 2, p. 209-243, 1980.

WOODING, F. B. P. Current topic: the synepitheliochorial placenta of ruminants: binucleate cell fusions and hormone production. Placenta, v. 13, p.101-113, 1992.

WOODING, F. B. P.; MORGAN, G.; ADAM, C. L. Structure and function in the ruminant synepiteliocorial placenta: central role of the trofoblasto binucleated cells in deer.

Microscopy Research and Technique, v. 38, p. 88-99, 1997. 